\title{
Differential Expression of Connexins during Neocortical Development and Neuronal Circuit Formation
}

\author{
B. Nadarajah, ${ }^{1}$ A. M. Jones, ${ }^{2}$ W. H. Evans, ${ }^{2}$ and J. G. Parnavelas ${ }^{1}$ \\ ${ }^{1}$ Department of Anatomy and Developmental Biology, University College London, London WC1E 6BT, United Kingdom, \\ and ${ }^{2}$ Department of Medical Biochemistry, University of Wales College of Medicine, Cardiff CF4 4XN. United Kingdom
}

Gap junctions are membrane channels that mediate the direct passage of ions and molecules between adjacent cells. Recent tracer coupling and optical recording studies have revealed the presence of gap junction-mediated communication between neurons during neocortical development. We have visualized gap junctions in the developing rat cerebral cortex with electron microscopy and studied the pattern of expression and cellular localization of connexins 26,32 , and 43 that take part in their formation. We found that these connexins (Cxs) are expressed differentially during development, and their patterns of expression are correlated with important developmental events such as cell proliferation, migration, and formation of cortical neuronal circuits. Specifically, we observed that the developmental profile of
Cx 26 during the first 3 weeks of postnatal life matched closely the development of neuronal coupling, suggesting that coupled neurons use this gap junction protein during circuit formation in the cortex. The subsequent diminution of Cx 26 was mirrored by an increase in Cx 32 immunoreactivity, which became pronounced at the late stages of cortical maturation. In contrast, Cx 43 was localized in the cortex throughout the period of development. Its localization in radial glial fibers closely associated with migrating neurons suggests that this Cx may be involved in neuronal migration.

Key words: connexin 26; connexin 32; connexin 43; gap junctions; development; neocortex; immunocytochemistry; electron microscopy
Intercellular communication by means of gap junctions is widespread in the developing nervous system and is believed to play a role in a number of developmental events such as regional differentiation, axon growth and guidance, and synapse formation (Guthrie and Gilula, 1989; Fulton, 1995). During the early development of the cerebral cortex, when synapses are sparse and synaptic activity is low, a nonsynaptic mechanism of intercellular communication could enable maturing neurons to interact more directly. This notion has been supported by evidence of extensive dye coupling between precursor cells in the ventricular zone (LoTurco and Kriegstein, 1991) and between neocortical neurons during circuit formation (Connors et al., 1983; Peinado et al., 1993a). Furthermore, optical recordings using $\mathrm{Ca}^{2+}$-sensitive dyes have demonstrated the presence of "neuronal domains" in the developing cortex that are abolished by halothane and octanol, substances known to block gap junctions (Yuste et al., 1992, 1995). The spatial similarities of interneuronal dye coupling and the optically recorded neuronal domains suggest that both methods reveal the same organization of low resistance pathways between neurons in the developing cortex (Peinado et al., 1993b).

Gap junctions are the morphological correlates of dye coupling and low resistance intercellular pathways. In electron micrographs

Received Dec. 19, 1996; revised Feb. 7, 1997; accepted Feb. 12, 1997.

This work was supported partially by a Medical Research Council program grant to W.H.E. We thank Audrey Dooley for providing the cell cultures, John F. R. Cavanagh for help with the illustrations, Brett Harris for printing, and Kate Whitley for assistance with confocal microscopy.

Correspondence should be addressed to Bagirathy Nadarajah, Department of Anatomy and Developmental Biology, University College London, Gower Street, London WC1E 6BT, UK.

Copyright (C) 1997 Society for Neuroscience $0270-6474 / 97 / 173096-16 \$ 05.00 / 0$ they appear as heptalaminar structures between intimately apposed plasma membranes separated by a distance of 2-3 nm (Brightman and Reese, 1969). A gap junction channel, formed by two hemichannels each composed of six connexin $(\mathrm{Cx})$ proteins, is permeant to ions, small organic metabolites, and second messengers of up to $1 \mathrm{kDa}$ (Bennett et al., 1991). Thirteen rodent Cxs have now been identified, and in the mammalian brain Cxs 26, 32, and 43 are the major isoforms (Dermietzel and Spray, 1993; Kumar and Gilula, 1996). Their expression in various regions of the developing and adult brain, including the cerebral cortex, has been studied by Dermietzel et al. (1989), who showed that Cx 43, a major $\mathrm{Cx}$ in the rodent brain generally associated with astrocytes, is expressed prenatally and in abundance postnatally. Cx 32 is expressed by neurons and oligodendrocytes from the second week of life, whereas $\mathrm{Cx} 26$, present predominantly during the earlier phases of development, is later restricted to non-neuronal cells in the ependyma and leptomeninges.

Electrophysiological studies in the cortex have shown that dye coupling between neurons is developmentally regulated. Peinado and colleagues (1993a,b) have found that between days 5 and 12, as many as $66 \%$ of single neurons injected with Neurobiotin labeled clusters of up to 80 neurons around the injected cell. The incidence of coupling decreased dramatically, starting at the end of the second postnatal week, until it involved only a very small number of cells. We hypothesized that this change in coupling during development is matched by changes in Cx expression. With use of electron microscopy and cell and molecular biological techniques, we have studied gap junctions and the expression of their constituent connexins (Cxs 26, 32, and 43) in the developing cerebral cortex from early embryonic life to maturity. The results demonstrate that gap junctions are abundantly present at all 
stages of cortical development. We also show that the three Cxs are differentially expressed during development, and their patterns of expression and cellular localization are correlated with important developmental events such as neurogenesis, cell migration, and neuronal circuit formation in the cortex.

\section{MATERIALS AND METHODS}

Connexin antibodies. The anti-peptide antibodies used in the present study have been characterized extensively in rodent tissues and have been used recently to investigate the distribution of Cxs 32 and 43 in the adult cerebral cortex (Nadarajah et al., 1996). Briefly, peptides with stated sequences were synthesized and coupled to hemocyanin, and antibodies were generated in rabbits. The $\mathrm{Cx} 26$ antibody was raised against the amino acid sequence 106-119 of rodent Cx 26 (located in the intracellular loop) and characterized by immunocytochemistry and Western blotting in various rodent and human tissues (Monaghan et al., 1994, 1996). The Cx 43 antibody, raised against residues 131-142 of rodent $\mathrm{Cx} 43$ (located in the intracellular loop), has been characterized by immunocytochemistry in mouse breast, heart, and liver, and in pig endothelial cells (Monaghan et al., 1994, 1996; Becker et al., 1995; Carter et al., 1996). The Cx 32 antibody, raised against the sequence 108-119 of rodent Cx 32 (located in the intracellular loop), has been similarly studied by Western blotting in rodent liver (Rahman and Evans, 1991; Rahman et al., 1993).

Connexin immunocytochemistry. Twelve embryonic brains obtained from four heavily anesthetized pregnant rats, each at 12,14, 16 and $19 \mathrm{~d}$ of gestation, were fixed by immersion in $2 \%$ paraformaldehyde in $0.1 \mathrm{M}$ PBS, pH 7.2-7.4, for 15-20 min. The day in which a vaginal plug was found in pregnant rats was considered embryonic day 1 (E1). The brains were subsequently cryoprotected in $12 \%$ sucrose, frozen in OCT, and cut in the coronal plane with a cryostat at $12 \mu \mathrm{m}$. This tissue was used to study Cx 26 and 43 expression. Coronal sections, taken from rapidly frozen brains of embryos of the same ages, were fixed in methanol (5 min at $4^{\circ} \mathrm{C}$ ) and used for $\mathrm{Cx} 32$ labeling. Analysis of $\mathrm{Cx}$ expression during postnatal life was performed in five Sprague Dawley albino rats, each at postnatal day (P) 0, P3, P7, P14, P21, and P28. These animals were anesthetized with ether, and their brains were removed and frozen rapidly in isopentane chilled in liquid nitrogen. They were sectioned with a cryostat in the sagittal plane, starting at the midline, at a thickness of 10 $\mu \mathrm{m}$. Sections used for Cx 32 immunoreactivity were fixed in methanol for 5 min at $4^{\circ} \mathrm{C}$, whereas those used for Cxs 26 and 43 were fixed with $4 \%$ paraformaldehyde in $0.1 \mathrm{M}$ PBS for $10 \mathrm{~min}$. Positive controls were performed in sections cut from rapidly frozen rat liver (Cxs 26 and 32) and heart ( $\mathrm{Cx} 43)$ tissues, whereas sections treated with preimmune serum were used as negative controls. The protocol used for $\mathrm{Cx}$ immunocytochemistry was as follows. Sections were blocked for nonspecific labeling with $5 \%$ normal goat serum, $0.1 \mathrm{M} \mathrm{L}$-lysine, and $0.1 \%$ bovine serum albumin, followed by incubation with $\mathrm{Cx}$ antibodies $(1: 100)$ at $4^{\circ} \mathrm{C}$ overnight. Goat anti-rabbit conjugated to biotin (1:100; Vector Laboratories, Burlingame, CA) was used as second layer, with streptavidin fluorescein (1:100; Amersham, Arlington Heights, IL) as third layer. Specificity of staining was assessed further by substituting the primary antibody with antibody preadsorbed with a range of concentrations of corresponding peptides (final concentration $20-100 \mu \mathrm{g} / \mathrm{ml}$ of antibody solution) in sections of liver, heart, and brain. All sections were examined and analyzed with a Leica TCS 4D laser-scanning confocal microscope.

Twenty serial sections, collected from the anterior telencephalic vesicles of each embryo, were used to analyze the density and distribution of Cx 26 and 43 immunoreactivities. Alternate sections were used for each antigen, and for every section analyzed, a sequential series of images together spanning the entire thickness of the developing dorsal telecephalic wall was collected. Similarly, for quantitative analysis of the three Cxs in postnatal ages, a sequential series of images were collected from 30 serial sections taken from each animal. Analysis of density distribution of immunoreactive particles was performed as described previously (Gourdie et al., 1991; Nadarajah et al., 1996), using the PC-Image image analysis package (Foster Finlay Associates, Newcastle, UK). Briefly, a $3 \times 3$ median filter was passed over the whole image to remove background noise and single pixels. The pixel intensity threshold was then adjusted to a range from 70 to 255 on the $0-255$ level gray scale, such that all the brightly labeled particles were demarcated by an overlying binary image. The automatic measurement of the number of particles was then performed by the software.

Double-immunofluorescence labeling. To characterize the expression of constituent Cxs in developing cortical cell types, double-immunolabeling experiments were performed in tissue sections, in acutely dissociated cortical cell preparations, and in dissociated cell cultures prepared from the cerebral cortices of E16 rat fetuses. The brains of three rats at each of P0, P7, P14 and $\mathrm{P} 21$ were cut coronally into 3- to 4-mm-thick slices, immersed in $2 \%$ paraformaldehyde in $0.1 \mathrm{M}$ PBS for 20-30 min, cryoprotected in $12 \%$ sucrose, and frozen in OCT. Sections, $12 \mu \mathrm{m}$ in thickness, were cut with a cryostat from the visual cortices (Krieg, 1946) and stained for one of the Cxs (Cxs 26, $32,43)$ as well as for one of the following cell-specific markers: microtubuleassociated protein 2 (MAP-2) (neurons, monoclonal, dilution 1:500; Boehringer Mannheim, Indianapolis, IN), glial fibrillary acidic protein (GFAP) (astrocytes, monoclonal, dilution 1:500; Sigma, St. Louis, MO), S-100 (astrocytes, monoclonal, dilution 1:1000; donated by Dr. G. Campbell, University College London). Similarly, cryostat-cut sections of E19 rat brains were fixed as mentioned above (see Cx immunocytochemistry) and double-labeled for one of the Cxs (Cxs 26, 43; Cx 43, monoclonal, dilution 1:40; Affinity) and one of the following cell-specific markers: MAP-2, intermediate filament nestin (undifferentiated neuroepithelial cells, polyclonal; donated by Dr. R. McKay, National Institutes of Health). Goat anti-rabbit conjugated to FITC (Sigma) and goat anti-mouse conjugated to biotin (IgG, Vector) were used as second layers (1:100), followed by streptavidin Texas Red (1:100; Amersham)

To estimate the percentage of neurons immunolabeled for $\mathrm{Cx} 26$, coronal sections cut through the visual cortex of each of three brains at P3, P7, and P14 were examined. Five sections from each brain, $12 \mu \mathrm{m}$ in thickness and spaced $60 \mu \mathrm{m}$ apart, were collected and labeled for $\mathrm{Cx} 26$ immunoreactivity [using the avidin-biotin complex (ABC) method with diaminobenzidine as a chromogen], counterstained with toluidine blue, dehydrated, and mounted with glycerol. Cx 26-labeled neurons as well as unlabeled cells were counted in strips of cortex between the pia and the subcortical white matter, and frequencies of Cx 26-labeled neurons were established.

To characterize in greater detail the constituent Cxs in single cortical cell types, double-immunolabeling experiments were performed in acutely dissociated cell preparations obtained from the cerebral cortices of two neonatal rat brains. The cortices were dissected and incubated in HBSS containing $0.1 \%$ trypsin, $0.01 \%$ DNase at $37^{\circ} \mathrm{C}$ for $30 \mathrm{~min}$. Tissue pieces were incubated for an additional 10 min with $0.02 \%$ EDTA and $0.01 \%$ trypsin in HBSS at $37^{\circ} \mathrm{C}$. Heat-inactivated fetal calf serum (FCS) was added to inactivate trypsin at the end of incubation. After mechanical dissociation, the supernatant containing the dissociated single cells was collected and centrifuged at $500 \times$ $g$ for $3 \mathrm{~min}$, and the cells were resuspended in $1 \mathrm{ml}$ of DMEM. Cells were plated on poly-L-lysine/laminin-coated glass coverslips and after $20 \mathrm{~min}$ were fixed with $2 \%$ paraformaldehyde for $10 \mathrm{~min}$ or with methanol $\left(5 \mathrm{~min}\right.$ at $\left.4^{\circ} \mathrm{C}\right)$ and processed for $\mathrm{Cx}$ immunoreactivity as well as for one of the various cell-specific markers.

To assess the potential of differentiating cortical neuroepithelial cells to express Cxs, an in vitro model was used. The cerebral cortices of E16 rat brains were dissected, cleared of meninges, and enzymatically dissociated by incubation in DMEM (ICN Biochemicals, Montréal, Québec, Canada) containing 0.1\% trypsin (ICN) and $0.001 \%$ DNase I (Boehringer Mannheim), for $30 \mathrm{~min}$ at $37^{\circ} \mathrm{C}$. After they were washed in $\mathrm{Ca}^{2+} / \mathrm{Mg}^{2+}$-free HBSS, treatment was continued with $0.05 \%$ trypsin, $0.002 \%$ DNase I, and $0.5 \mathrm{~mm}$ EDTA (Sigma) in HBSS for $12 \mathrm{~min}$. Inactivation of trypsin was performed by the addition of $10 \%$ active FCS (Life Technologies, Gaithersburg, MD), and the tissue pieces were dissociated by gentle trituration using a pipette. The resulting cell suspension was centrifuged and resuspended in DMEM/F12 (Sigma). Cells were plated on poly-L-lysine/laminin-coated coverslips at a density of $2 \times 10^{5}$ cells/coverslip. Culture plates were kept in a humidified $95 \%$ air $/ 5 \% \mathrm{CO}_{2}$ incubator at $37^{\circ} \mathrm{C}$, and cells were allowed to attach in this medium for $30 \mathrm{~min}$, after which they were maintained in DMEM/ F12 containing 10\% FCS, 2 mM L-glutamine (ICN), and penicillin/ streptomycin (PS; ICN) in mixture for $24 \mathrm{hr}$. After this stabilization period, cultures were washed in DMEM and placed in N-2-defined medium (Life Technologies) supplemented with $1 \%$ FCS, PS, and 2 $\mathrm{mm}$ glutamine in DMEM/F12 for up to $7 \mathrm{~d}$. Media and reagents were partially replaced every $2-3$ d. Cells were fixed as mentioned previously and processed for immunocytochemistry for one of the Cxs and cellspecific markers.

Digoxigenin $(D I G)$ in situ immunocytochemistry. The vector pcDNA 1 Neo (Invitrogen, San Diego, CA) containing rat Cx 26 cDNA (Zhang and Nicholson, 1989) was linearized with HindIII restriction enzyme and used to make DIG-labeled Cx 26 antisense probes with SP6 RNA polymerase. The brains of two rats at P6 were fixed by cardiac perfusion with $4 \%$ paraformaldehyde in $0.1 \mathrm{M}$ PBS and cut with a cryostat at $12 \mu \mathrm{m}$. 
Prehybridization $\left(3 \mathrm{hr}\right.$ at $\left.55^{\circ} \mathrm{C}\right)$ and hybridization (overnight at $55^{\circ} \mathrm{C}$ ) of sections were followed by stringent washes $\left(2 \times \mathrm{SSC}\right.$ at $55^{\circ} \mathrm{C}$ for $15 \mathrm{~min}$, twice; $0.2 \times \mathrm{SSC}$ at $55^{\circ} \mathrm{C}$ for $15 \mathrm{~min}$, twice; $1 \times \mathrm{PBS}$ at room temperature). The probed sections were then processed for immunocytochemistry with one of the following cell-specific markers: MAP-2, GABA (nonpyramidal neurons, polyclonal, 1:500; Sigma), GFAP, and S-100. Goat anti-rabbit conjugated to biotin was used as second layer, and streptavidin Texas Red with anti-DIG conjugated to FITC (1:200; Boehringer) as third layer. All incubations were performed at room temperature, each for $2 \mathrm{hr}$, and washes were performed in between with PBS ( 5 min, 3 times). Sections were mounted with Citiflor and analyzed using the confocal microscope. Specificity of the Cx 26 RNA labeling was ascertained with sense probes as well as with use of tissue controls (rat liver and heart were used as positive and negative controls).

Electron microscopy. The heads of embryonic rats (E12-E19) were cut off and immersed in $4 \%$ paraformaldehyde in $0.08 \mathrm{M}$ cacodylate buffer, $\mathrm{pH} 7.2-7.4$, at $4^{\circ} \mathrm{C}$ for $30 \mathrm{~min}$ before the brains were removed. The telencephalic vesicles were cut by hand into coronal slices and reimmersed for 3-4 hr in fixative solution containing $4 \%$ paraformaldehyde and $2.5 \%$ glutaraldehyde in $0.08 \mathrm{M}$ cacodylate buffer, $\mathrm{pH}$ 7.2-7.4. The slices were post-fixed in $2 \% \mathrm{OsO}_{4}$ in cacodylate buffer for $2 \mathrm{hr}$, stained in $0.5 \%$ aqueous uranyl acetate for $45 \mathrm{~min}$, dehydrated in ethanol, and embedded in Araldite. Ultrathin sections of silver-gold interference color $(\sim 80 \mathrm{~nm})$ were cut through the dorsal telencephalic wall of the anterior telencephalic vesicle, collected on 200-mesh grids, and examined with a JEOL 1010 electron microscope.

Preembedding immunocytochemistry was also performed for nestin labeling in coronally cut slices of two E19 rat brains. The slices were fixed with $4 \%$ paraformaldehyde in $0.1 \mathrm{M}$ phosphate buffer for $30 \mathrm{~min}$ and processed for nestin immunocytochemistry using the ABC method. They were then processed for electron microscopy and embedded in Araldite.

Western blotting. Visual cortices dissected from 20 brains each from newborn and P7 rats, and 15 brains each from P14 and P21 animals were taken along with age-matched liver and heart tissues and homogenized in $1 \mathrm{~mm}$ $\mathrm{NaHCO}_{3}$ buffer. All steps were performed at $4^{\circ} \mathrm{C}$, and a solution of protease inhibitors $(10 \mu \mathrm{g} / \mathrm{ml}$ of leupeptin, aprotinin, and pepstatin A) and freshly prepared phenylmethylsulfonyl fluoride $(1 \mathrm{~mm})$ was added at intervals throughout the extraction procedure. Membrane fractions were prepared by centrifugation from the homogenates, and after sonication they were extracted with $20 \mathrm{~mm} \mathrm{NaOH}$ (Hertzberg, 1984). Protein $(60 \mu \mathrm{g})$ was analyzed by $12.5 \%$ SDS-PAGE (Laemmli, 1970) and transferred electrophoretically onto a nitrocellulose membrane. Amersham rainbow relative molecular weight markers $\left(M_{\mathrm{r}} 14.3-200 \mathrm{k}\right)$ were used. Membranes, blocked with $1 \%$ dry skimmed milk in PBS containing $0.1 \%$ Tween 20 for $30 \mathrm{~min}$, were incubated with $\mathrm{Cx}$ antibodies $(1: 500)$ overnight at $4^{\circ} \mathrm{C}$. Incubations with biotinylated donkey anti-rabbit (1:200; Amersham) and streptavidin-biotin complex conjugated to alkaline phosphatase (1:100; Vector) were performed for $2 \mathrm{hr}$, each at room temperature. Control experiments were performed using antibodies preadsorbed with corresponding peptides (final concentration $40 \mu \mathrm{g} / \mathrm{ml}$ of antibody solution). Antibody binding was visualized by reaction with nitro blue tetrazolium and 5-bromo-4-chloro-3-indolyl phosphate in alkaline phosphatase buffer.

Northern blotting. Total RNA was extracted from the visual cortices of four newborn rats-two P14, one P28, and one P42 animal-by a single-step method using Ultraspec (Biotecx, Houston, TX). Twenty micrograms of total RNA were resolved by $1 \%$ agarose-formaldehyde gel containing ethidium bromide. Gels were then capillary-blotted onto a nylon membrane (Hybond- $\mathrm{N}^{+}$; Amersham) overnight in $10 \times$ SSC and fixed by ultraviolet light. The vector pcDNA 1 Neo (Invitrogen) containing three different $\mathrm{Cx}$ cDNAs-rat $\mathrm{Cx} 26$ cDNA (Zhang and Nicholson, 1989), rat Cx 32 cDNA (Paul, 1986), and rat Cx 43 cDNA (Beyer et al., 1987) - was used to produce antisense RNA probes. These vectors were linearized using specific restriction enzymes, and the DIG-labeled Cxs 26, 32, and 43 antisense RNA probes were produced using the DIG-RNA labeling kit (Boehringer Mannheim). Hybridization and washing were performed under stringent conditions. The blots were washed with $2 \times \mathrm{SSC} / 0.1 \%$ SDS for $2 \times 5 \mathrm{~min}$ at room temperature and with $0.1 \times \mathrm{SSC} / 0.1 \% \mathrm{SDS}$ for $4 \times 10 \mathrm{~min}$ at $68^{\circ} \mathrm{C}$. Detection was performed by the DIG colorimetric system (Boehringer Mannheim). After detection of each Cx RNA, the color precipitate was removed and probe-stripped off before the other antisense RNA probes were used. GAPDH antisense RNA was used as an internal control, whereas negative controls were performed with sense-RNA probes in the hybridization mixture. Densitometric analyses were performed to determine the hybridization intensity of the bands, and each one was normalized to the intensity of the GAPDH band in the same lane.

RT-PCR analysis was performed in all postnatal ages as described by Monaghan et al. (1996), using primers for Cxs 26, 32, 37, and 43.

\section{RESULTS Specificity of $\mathbf{C x}$ antibodies}

The specificity of Cx 32 and 43 antibodies used in this study has been described (Nadarajah et al., 1996). Briefly, the antibodies detected bands of $M_{\mathrm{r}} 27$ and $43 \mathrm{k}$ in liver and heart tissues, and they correspond to Cxs 32 and 43, respectively. Punctate staining characteristic of gap junctions was observed between hepatic cells (Cx 32) and in cardiac intercalated disks (Cx 43). Furthermore, sections of liver, heart, and brain tissues stained with preimmune serum or with preadsorbed antibodies showed no immunoreactivity; Western blots of the same tissue samples treated with preadsorbed antibodies were also negative. The specificity of the Cx 26 antibody used in this study is illustrated by the punctate pattern of gap junction staining observed between hepatocytes in liver sections (Nicholson et al., 1987) (Fig. 1a). Reduced immunoreactivity was observed in sections of liver and brain treated with antibody preadsorbed with $20 \mu \mathrm{g} / \mathrm{ml}$ of the peptide (Fig. 1b,d), whereas complete blockage of staining was obtained at a peptide concentration of $80 \mu \mathrm{g} / \mathrm{ml}$ (Fig. 1c,e).

\section{Connexin immunoreactivity and gap junctions Prenatal development}

Examination of sections through the dorsal telencephalic vesicles showed a differential expression of Cxs 26 and 43 between E12 and E19 (Figs. 2-4). No Cx 32 labeling was detected in any of the prenatal ages analyzed. At E12, Cx 43 appeared as punctate labeling found mostly between neuroepithelial cells lining the lateral ventricles (Fig. 2a), whereas Cx 26 immunoreactivity was present throughout the embryonic cortex but was more intense in a band along the ventricular surface (Fig. $2 d$ ). At the onset of cortical neurogenesis at E14, intense labeling for both proteins was present throughout the ventricular zone (Fig. 2b,e). Cx 26 labeling was especially intense in the perikaryal cytoplasm of cells, suggesting that most cortical progenitors synthesize this protein at this stage of development. With the radial expansion of the cortex in the subsequent few days, both proteins were present not only in the proliferative zones but throughout the thickness of the telencephalic wall (Figs. 2c,f, 3a,b). At E19, immunolabeling appeared considerably different, with Cx 26 labeling more concentrated in the proliferative zones than in the cortical plate (Fig. 3a,b). Quantitative analysis of levels of immunoreactivities in the proliferative zone (initially comprising only the ventricular zone and later including the subventricular zone) showed that $\mathrm{Cx} 26$ labeling was higher than $\mathrm{Cx} 43$ at all ages examined (Fig. 4B). The level of Cx 26 staining, corrected accordingly to take into account the radial expansion of the telencephalic vesicle (Bayer and Altman, 1991), was notably higher at E16 compared with other prenatal ages. Cx 43 levels, although highest at E16, were not significantly different when compared with levels at E14 ( $t$ test, two-tailed; $p<0.08$ ).

We also used electron microscopy to investigate the presence and spatial distribution of gap junctions with the characteristic sevenlayer appearance (Brightman and Reese, 1969) in the embryonic cortex. Early in corticogenesis (E12-E14), junctions were restricted between neighboring epithelial cells bordering the ventricle (Fig. $3 c, d$ ). At later embryonic stages (around E19), gap junctions were observed predominantly between the intermediate zone and the deep portion of the cortical plate, including the subplate (Fig. 3e).

To investigate the involvement of $\mathrm{Cx} 43$ in cortical neuronal migration, its expression was examined in radial glia, the cells that 

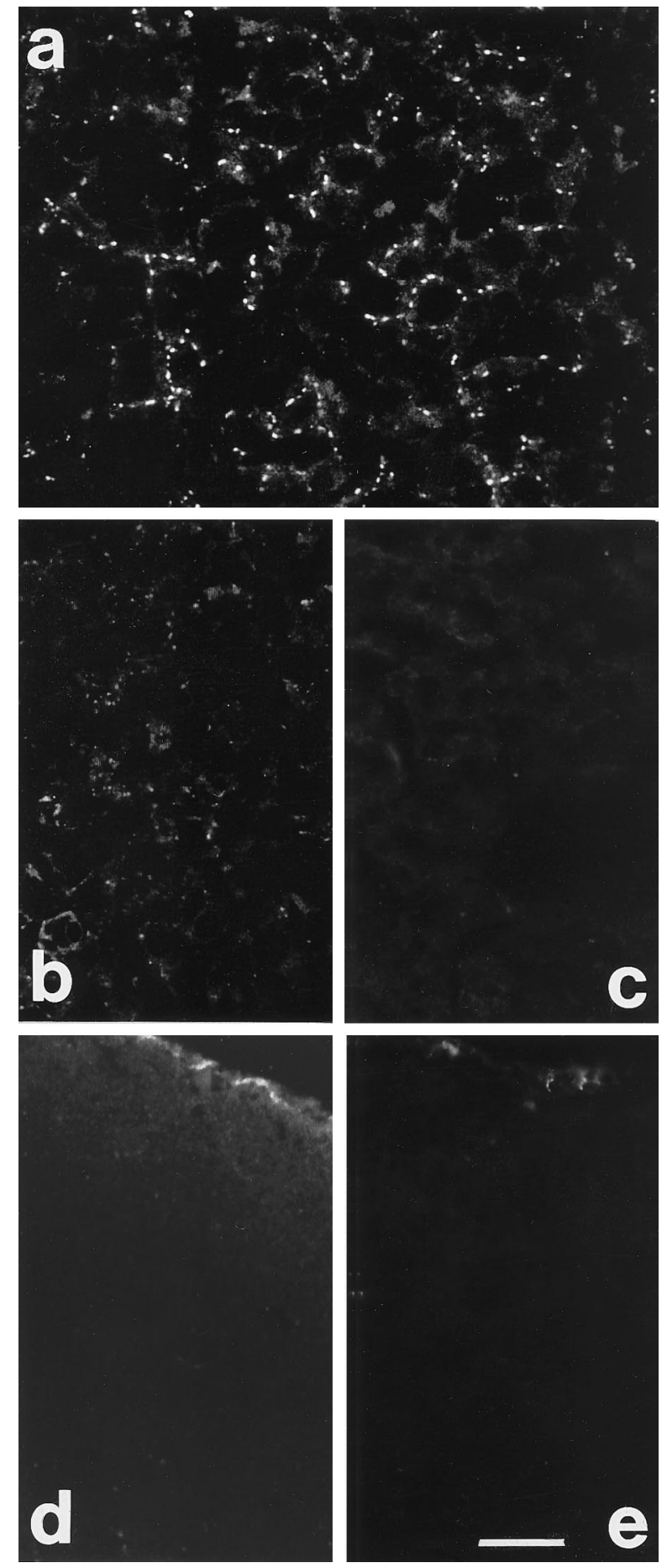

Figure 1. Cx 26 immunoreactivity in liver and brain. $a$, Labeling localized between hepatic cells in liver sections. $b, c$, Reduced labeling and absence of staining after treatment of sections with $\mathrm{Cx} 26$ antibody preadsorbed with $20(b)$ and $80 \mu \mathrm{g} / \mathrm{ml}(c)$ of peptide, respectively. $d, e$, Sections through the visual cortex of $\mathrm{P} 7$ rats treated with $\mathrm{Cx} 26$ antibody preadsorbed with $20(d)$ and $80 \mu \mathrm{g} / \mathrm{ml}(e)$ of peptide, respectively. Note the meningeal labeling (top of section); staining is much reduced in $d$ and completely blocked in $e$. Scale bar, $60 \mu \mathrm{m}$.

guide migrating neurons to their destinations in the cortical plate (Rakic, 1972). This was performed by double-immunolabeling sections of brains taken from E19 rat embryos for Cx 43, together with nestin, a marker of radial glial cells (Cameron and Rakic,
1991). Examination of these sections showed that nestin and Cx 43 antigens were frequently coexpressed in radially oriented processes spanning the thickness of the telencephalic wall (Fig. $5 a-c$ ). These labeled radial glial processes were often in contact with immature neurons as they migrated toward the cortical plate; however, because of an incompatibility between antibody labeling and fixation protocols, we were unable to unequivocally localize Cx 43 in gap junctions between migrating neurons and radial glial fibers. Electron microscopical examination confirmed the light microscopical findings by demonstrating clearly the presence of nestin-positive processes, oriented radially in the cortical plate, and intimately apposed by migrating neuronal somata (Fig. 5e). Moreover, it was fairly common to encounter gap junctions between nestin-positive and nestin-negative processes in the ventricular surface (Fig. 5d). Gap junctions were also detected between processes with electrolucent cytoplasmic matrix containing 9-10 $\mathrm{nm}$ glial intermediate filaments, characteristic of cells of the astroglial lineage (Rakic, 1972) (Fig. 5f).

\section{Postnatal development}

Examination of the postnatal development of $\mathrm{Cx}$ expression was performed in the visual cortex (presumptive area 17) (Krieg, 1946). Each of the three Cxs studied showed a unique pattern of postnatal development (Figs. 6, 7). At birth, Cxs 26 and 43 were detected as immunoreactive puncta distributed throughout the cortical thickness and were concentrated in the lower cortical layers (Fig. 6a,e). The average levels of immunoreactivity for both Cxs, determined by summing up all the labeled puncta in sections (10 sections from each of five animals), showed an increase between birth and P7 (Figs. 6a,b,e,f, 7) (Cx 26: two-tailed $t$ test, $p<0.001$; Cx 43: two-tailed $t$ test, $p<0.001)$. The level of $\mathrm{Cx} 26$ did not change appreciably during the second postnatal week (Fig. 7), after which it began to diminish (Figs. 6d,7) and was no longer detectable at P28. The expression of Cx 43, however, showed a continuous increase to P21 (Figs. $6 e-h, 7$ ). Punctate labeling of Cx 32, which was sparse until P14, became pronounced in the subsequent weeks, particularly in the lower layers of the cortex (Figs. $6 i-k, 7)$. In fact, as shown with $\mathrm{Cx}$ labeling in adult animals (Nadarajah et al., 1996), immunoreactive puncta of both Cx 32 and 43 were located predominantly in the infragranular layers of the cortex at $\mathrm{P} 28$, with $\mathrm{Cx} 43$ being the more abundant of the two proteins (Figs. $7 A$ ).

Double-labeling experiments with cell-specific markers in tissue sections of P3-P14 cortices showed that all cells labeled with Cx 26 antibody were positive for MAP-2 (Fig. $8 a$ ), strongly suggesting that this antigen is expressed in neurons; some of these neurons showed features of pyramidal cells (triangular somata and apical dendrites). Additional experiments using the glial markers GFAP or S-100 showed no colocalization with Cx 26 (Fig. $8 b)$. Examination of sections labeled by in situ hybridization showed that Cx 26 mRNA was contained in cell somata. These somata were also immunolabeled for MAP-2, thus confirming their neuronal identity; some of these neurons were GABAcontaining nonpyramidal cells (Fig. 8g). Astrocytes, labeled with GFAP or S-100 antibodies, did not show Cx 26 mRNA (Fig. 8h).

Quantification of Cx 26-immunolabeled neurons showed that at $\mathrm{P} 3$, these neurons constituted on average 35\% (SEM \pm 4.2$)$ of the cortical cell population; this increased to $48 \%$ at P7 (SEM \pm 5.5$)$ and reached $44 \%(\mathrm{SEM} \pm 4.8)$ at $\mathrm{P} 14$. We also noted during the first 2 weeks of life that a number of MAP-2-positive neurons, located predominantly in layers II/ III and V, also expressed Cx 43 (Fig. $8 c$ ). The pattern of staining of this antigen was similar to that 

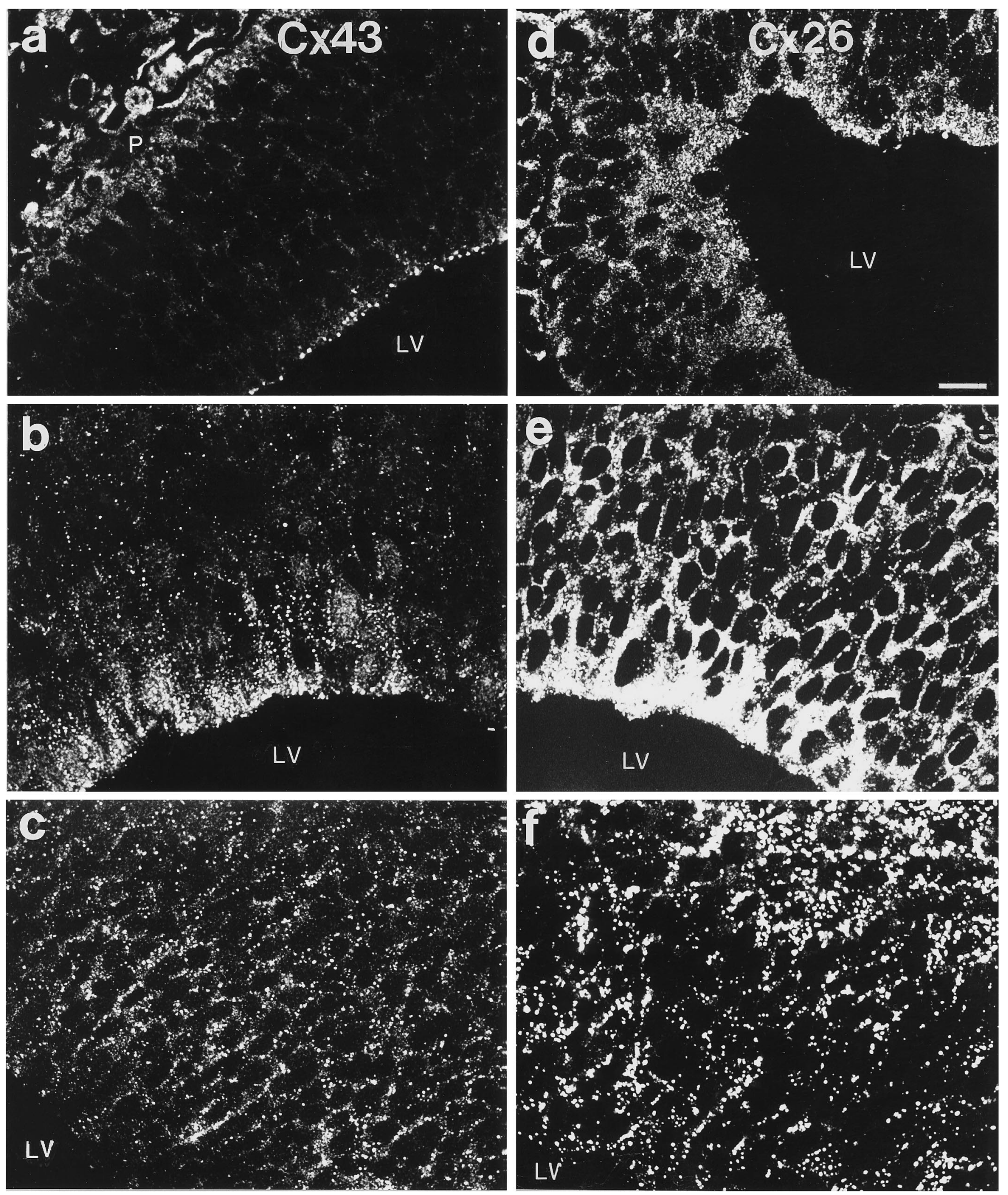

Figure 2. Cxs 26 and 43 immunolabeling in the dorsomedial telencephalic wall of E12-E16 rat brains. $a-c$, Examples of images taken from sections of E12 $(a)$, E14 (b), and E16 (c) brains labeled for Cx 43. Labeling at the pial surface $(P)$ of the brain in $a$ corresponds to Cx 43 immunoreactivity in meningeal components. $d-f$, Images from sections of brains of corresponding ages stained for $\mathrm{Cx} 26 . L V$, lateral ventricle. Scale bar, $32 \mu \mathrm{m}$. 

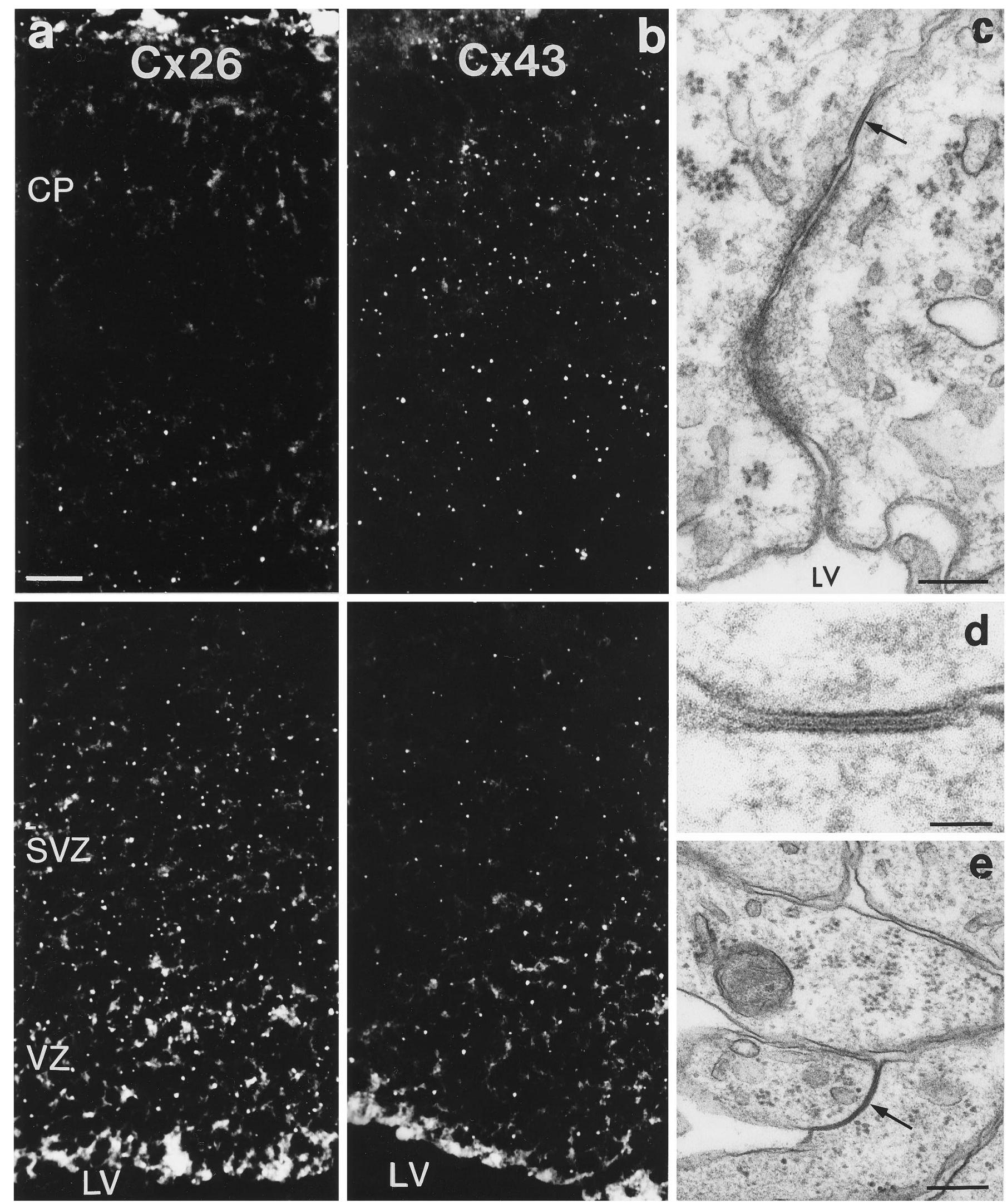

Figure 3. $a, b$, Cxs $26(a)$ and $43(b)$ immunolabeling in the dorsal telencephalic wall of an E19 rat brain. The top of each figure illustrates the distribution of $\mathrm{Cx}$ immunoreactivity in the marginal zone and part of the cortical plate $(C P)$, whereas the bottom of each figure illustrates Cx immunoreactivity in the proliferative zones $(V Z$ and $S V Z)$. Pial surface is at the top; $L V$, lateral ventricle. $c-e$, Examples of gap junctions in the embryonic cortex. One such junction, shown with an arrow in $c$ and at higher magnification in $d$, is between two cells in the lining of the lateral ventricle $(L V)$ at E16. The gap junction indicated with an arrow in $e$ is between two cell processes in the intermediate zone at E19. Scale bars: $a, b, 32 \mu \mathrm{m} ; c, e, 200 \mathrm{~nm} ; d, 50 \mathrm{~nm}$. 
A

Cx 26

Cx 43

$\mathbf{V Z}$

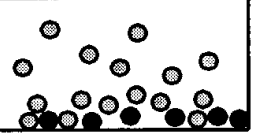

E12

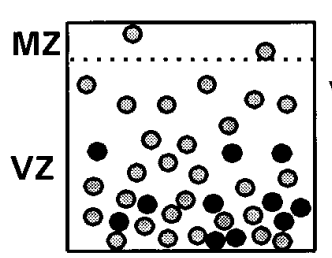

E14

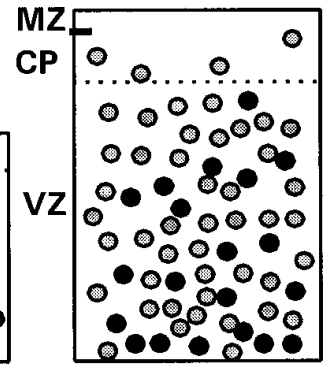

E16

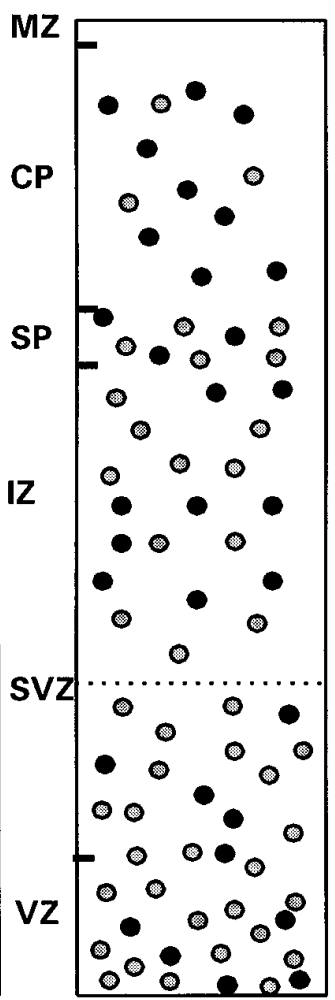

E19

B

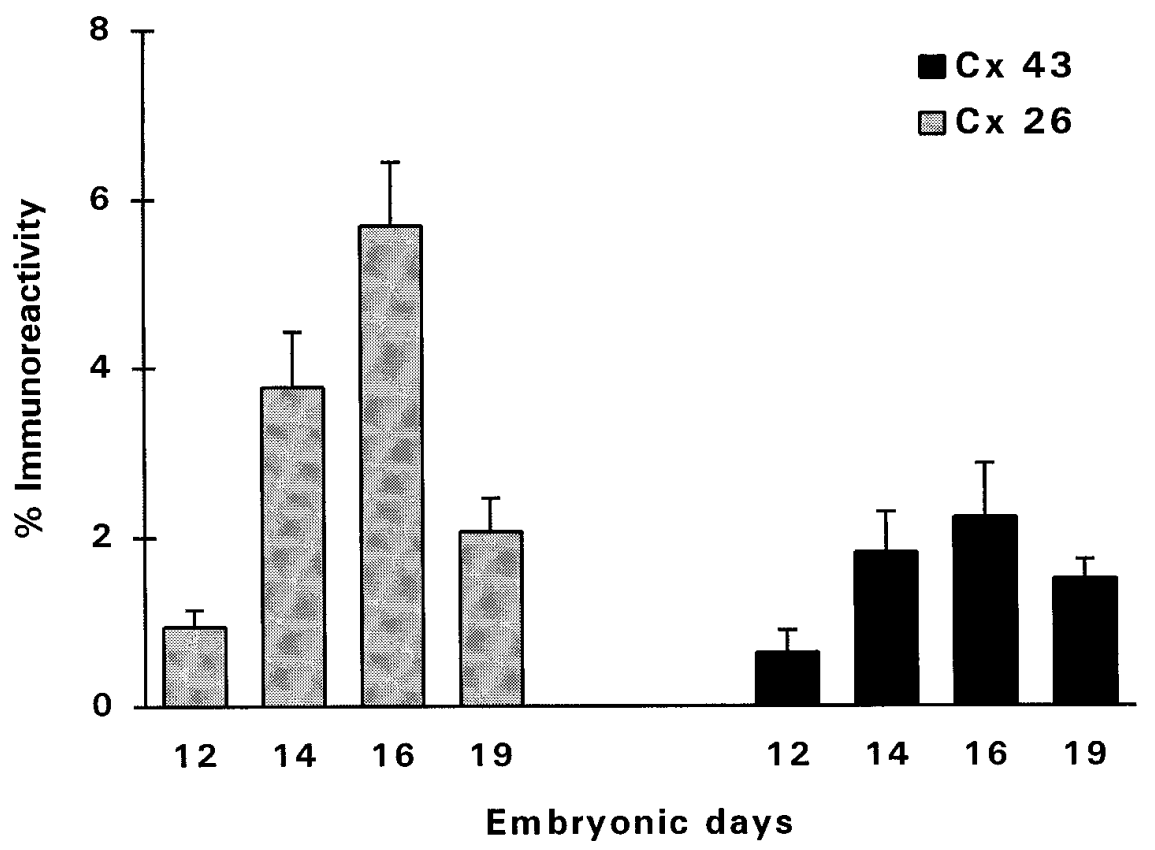

Figure 4. Expression of Cxs in the developing dorsal telencephalic wall of rat embryonic brains. $A$, Schematic representation of the pattern of distribution of $\mathrm{Cx} 26$ and 43 immunoreactivities at various stages of corticogenesis. At E12, Cx 26 was expressed throughout the neuroepithelium, whereas $\mathrm{Cx} 43$ was localized predominantly between cells bordering the ventricle. At E14-E16, both Cxs showed increased expression throughout the telencephalic wall. At E19, Cx 26 was more concentrated in the proliferative zones ( $V Z$ and $S V Z$ ), whereas $C x 43$ showed a more homogeneous expression through the thickness of the expanding telencephalic wall. $V Z$, Ventricular zone; $M Z$, marginal zone; $C P$, cortical plate; $S V Z$, subventricular zone; $I Z$, intermediate zone; $S P$, subplate. Measurements of immunoreactivity were performed in the $V Z$ at E12-E16, and in both the $V Z$ and $S V Z$ at E19; dotted lines indicate the upper limits of the areas measured. Scale bar, 80 $\mu \mathrm{m}$. $b$, Levels of immunoreactivity (\%) of Cxs 26 and 43 measured in the proliferative zones of 12 embryonic brains at each age. The measured levels were corrected, taking into account the radial expansion of the developing cortex. Error bars represent SEM. 

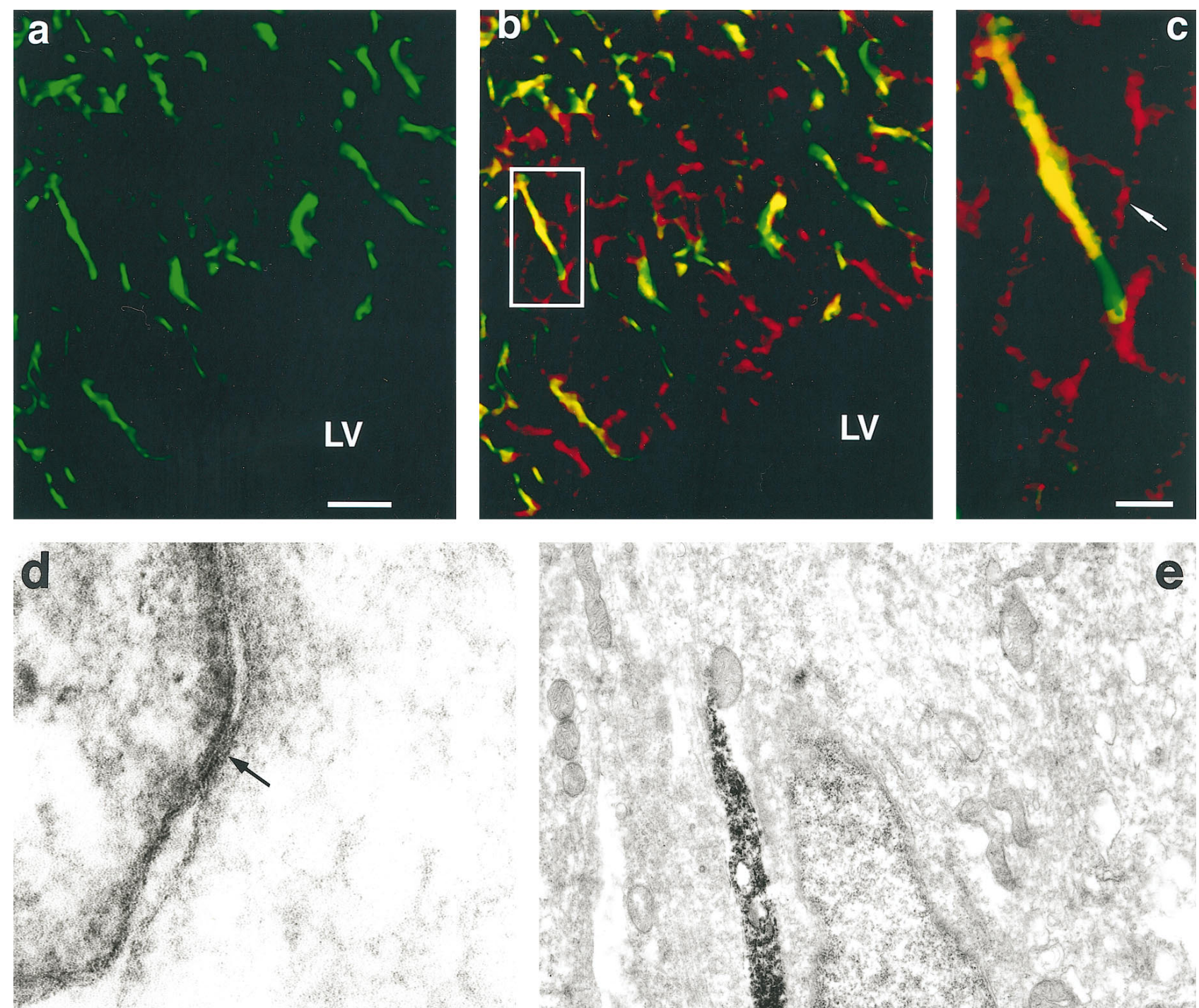

\section{LV}
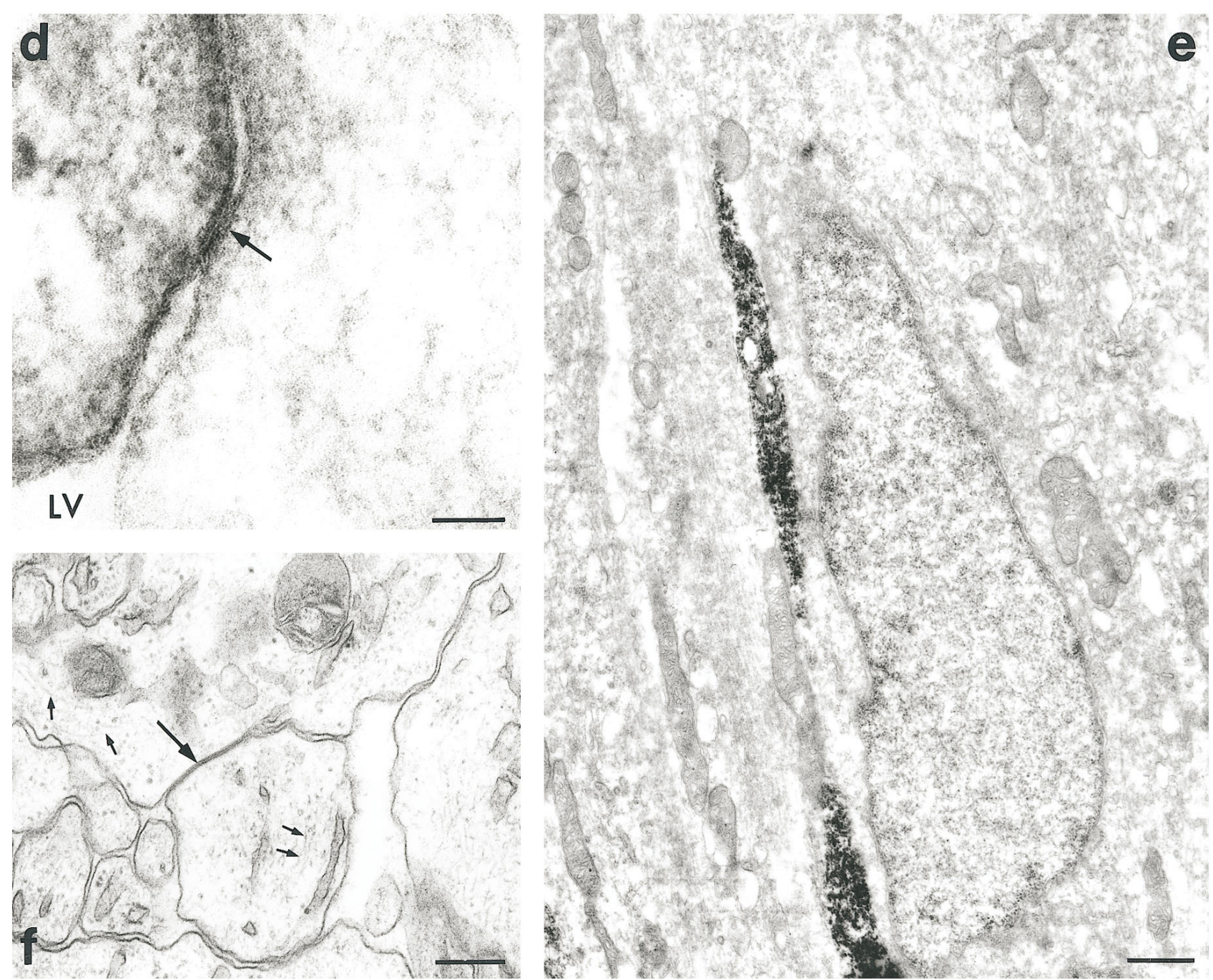

Figure 5. $a$, Nestin labeling ( green) of radial glial processes in the ventricular zone ( $L V$, lateral ventricle) at E19, and in $b$ together with punctate $C x 43$ labeling (red); points of colocalization of the two antigens appear yellow. An example of one such double-labeled radial glial process is contained within a rectangle and shown at higher magnification in $c$. At this higher magnification, the outline of a presumptive migrating cell (arrow) adjacent to the radial glial process can be recognized. Electron microscopic analysis revealed migrating neurons with leading and trailing processes intimately apposed to radially oriented nestin-positive processes $(e)$. Within the ventricular zone, gap junctions (arrow) were observed between nestin-positive and -negative processes $(d)$. $f$, Gap junctions $($ large arrow $)$ were also noted between cellular processes that contained bundles of intermediate filaments $(\sim 10 \mathrm{~nm}$; small arrows), indicative of astrocytes. Scale bars: $a$, $b$, $40 \mu \mathrm{m} ; c, 10 \mu \mathrm{m} ; d, 50 \mathrm{~nm} ; e, 780 \mathrm{~nm} ; f, 90 \mathrm{~nm}$. 
PO
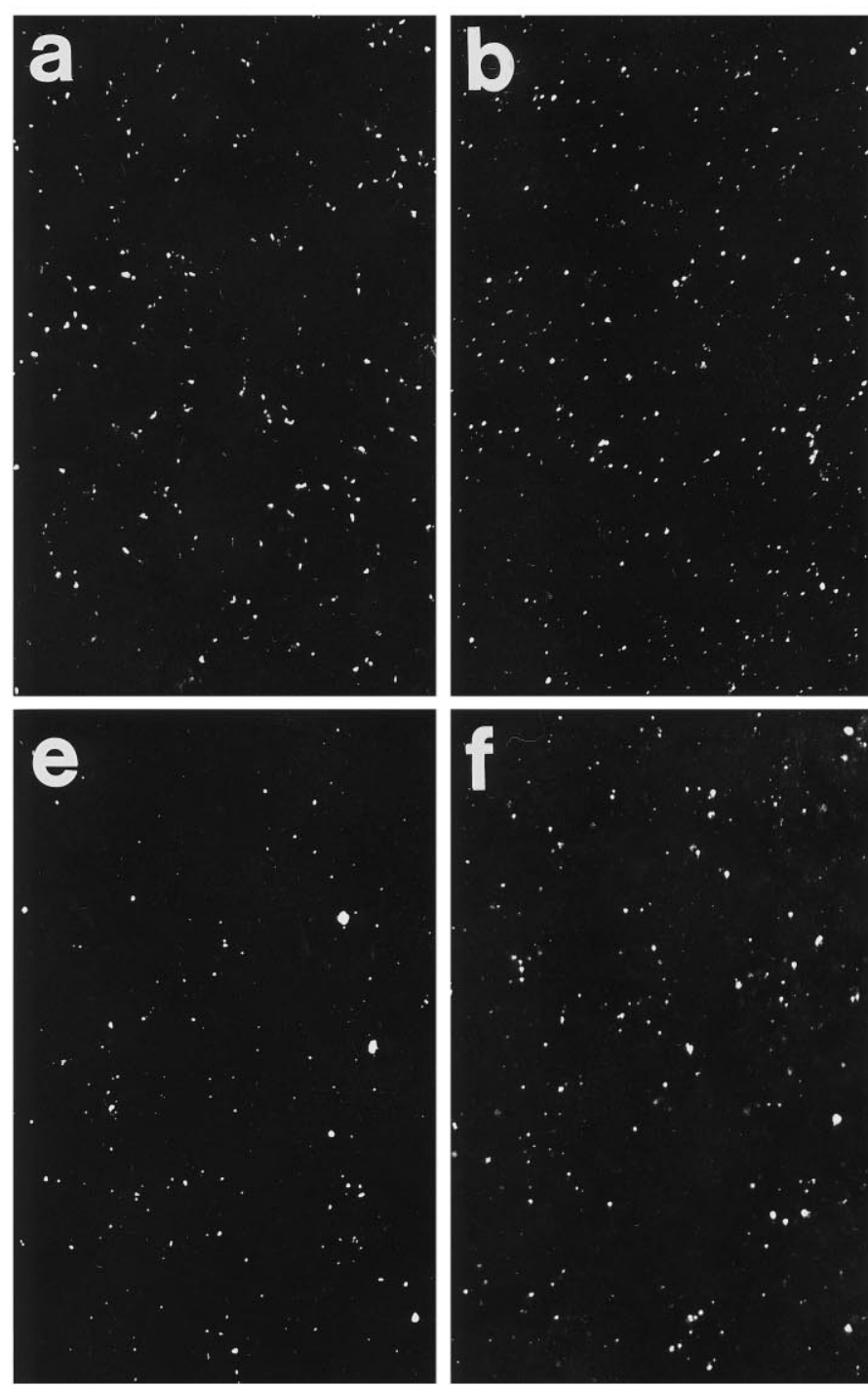

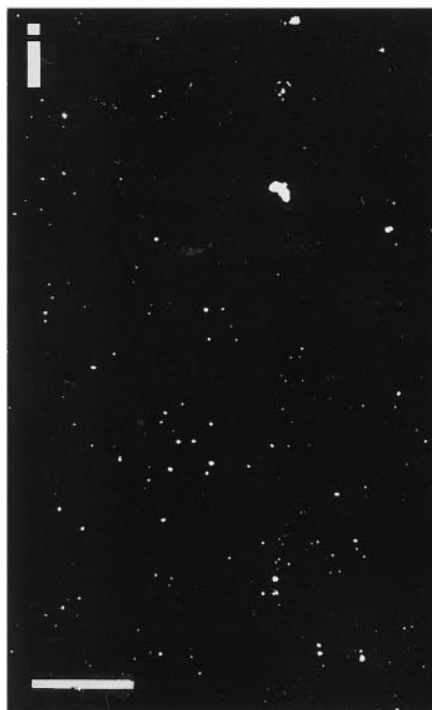

P14
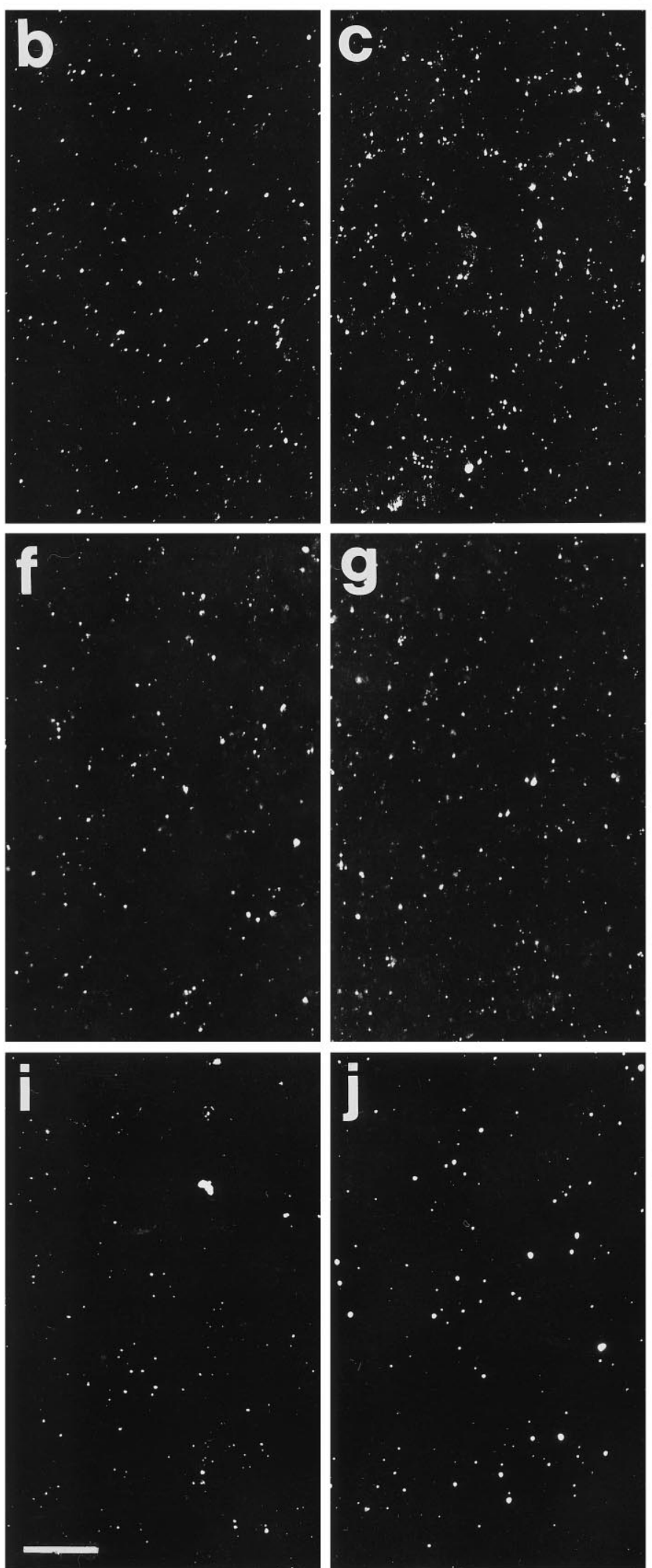

P21
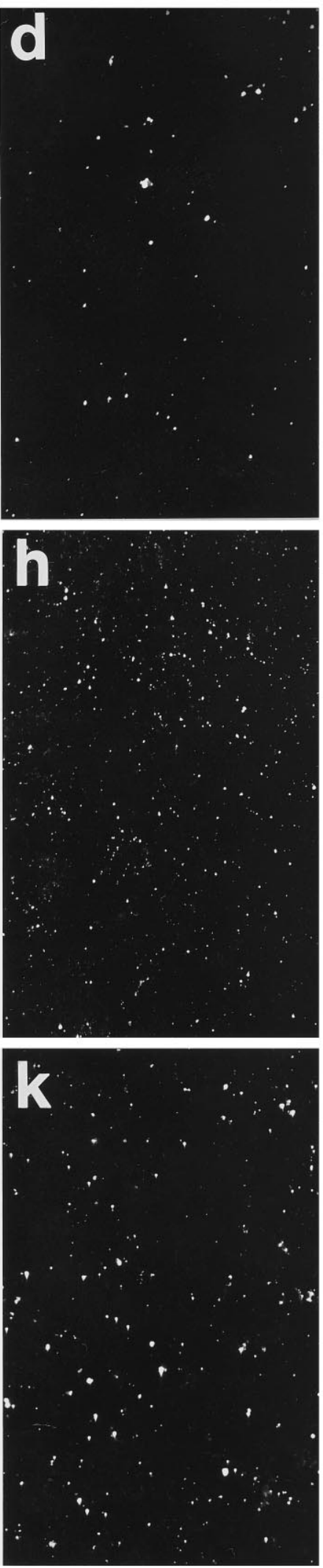

Figure 6. Examples of Cxs $26(a-d), 43(e-h)$, and $32(i-k)$ immunolabeling in the lower layers of the visual cortex during postnatal development (P0-P21). Note the differences between the three Cxs with regard to particle density and particle size in the developing cortex. Scale bar, $40 \mu \mathrm{m}$. 


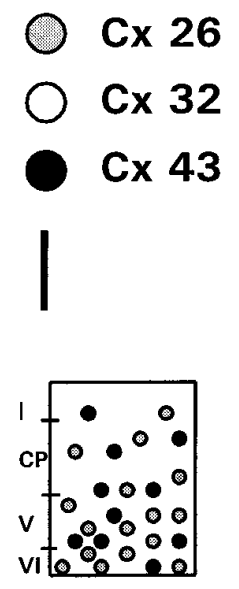

PO

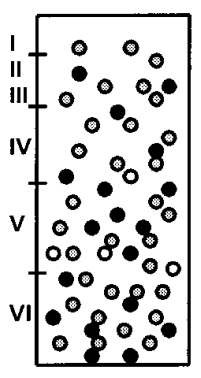

P7

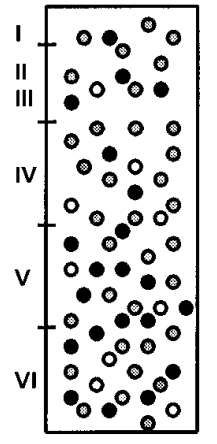

P14

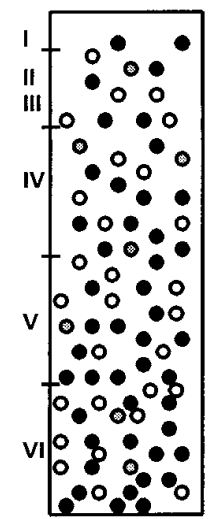

P21

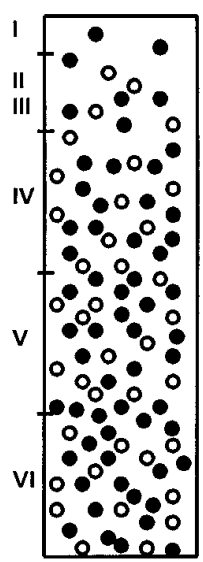

P28

B

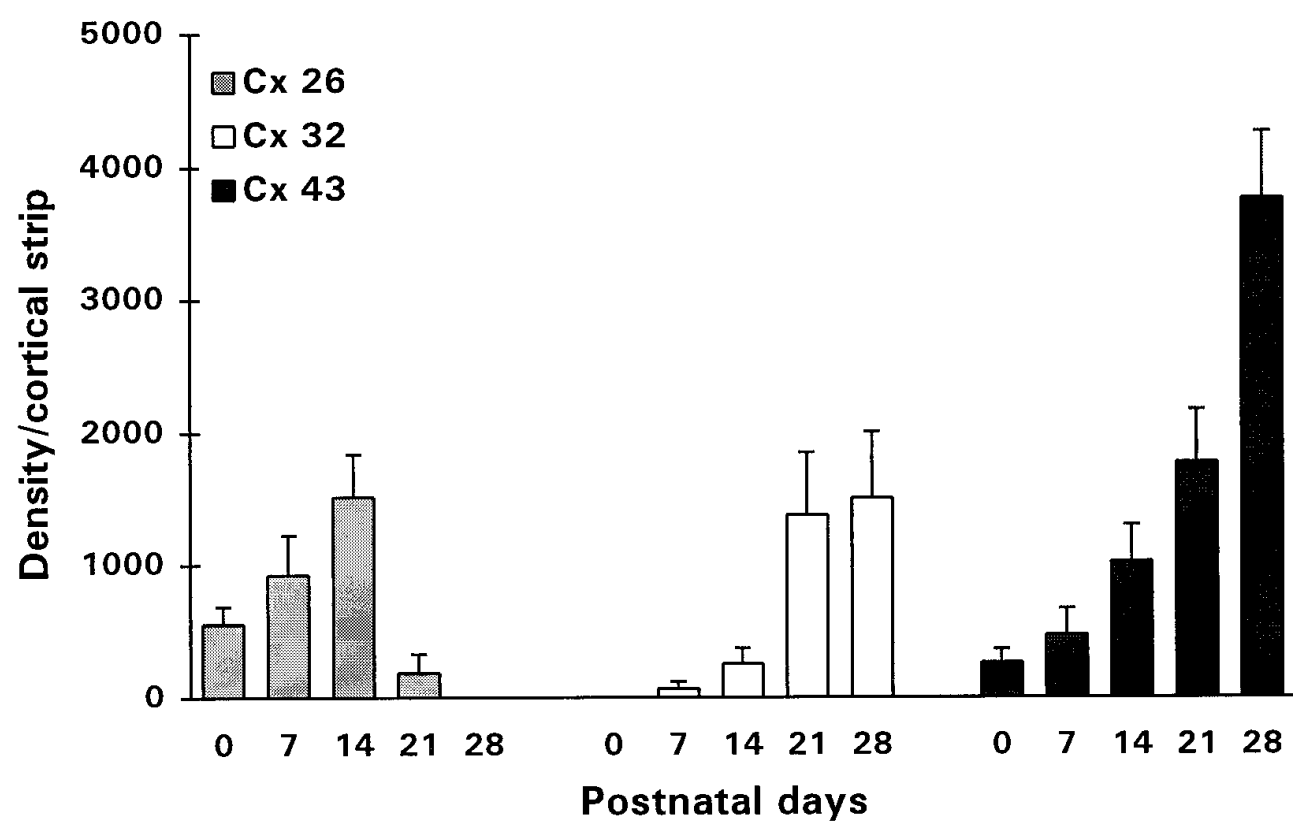

Figure 7. Expression of Cxs in the rat cerebral cortex during postnatal development. $A$, Schematic representation of the pattern of distribution of Cxs 26, 32, and 43 in the visual cortex between birth and P28. Scale bar, $200 \mu \mathrm{m}$. B, Average levels of Cxs 26,32 , and 43 immunoreactivities measured from sections of visual cortex of five rats at each of the ages shown. The levels were corrected according to Bayer and Altman (1991) to take into account the expansion of the cortex during postnatal development. Error bars represent SEM. of Cx 26, showing intensely labeled somata and dendrites of neurons. The coexpression of Cxs 26 and 43 in MAP-2-positive neurons was confirmed in acutely dissociated cortical cell preparations (Fig. 8e,f). In addition, and in agreement with earlier reports (Dermietzel et al., 1989), Cx 43 immunoreactivity was colocalized with S-100 or GFAP in a number of astrocytes scattered throughout the cortex (Fig. 8d).

\section{Expression of Cxs in vitro}

To characterize the neuroepithelial cells expressing the constituent Cxs during corticogenesis, double-immunolabeling ex- periments were performed in cortical cell cultures prepared from E16 rat brains. Cultures maintained for $3 \mathrm{~d}$ included a population of cells that coexpressed $\mathrm{Cx} 43$ and nestin (Fig. 8j). After 5-7 d in vitro, with most cells already differentiated into astrocytes or neurons, Cx 43 labeling was localized in the majority of cells, some of which were positive for GFAP (Fig. $8 k$ ). Cx 26 labeling was localized in most cells that had differentiated into neurons, as indicated by the presence of MAP-2 immunoreactivity, although some punctate labeling was visible in cells negative for this neuronal marker (Fig. 8i). The results 

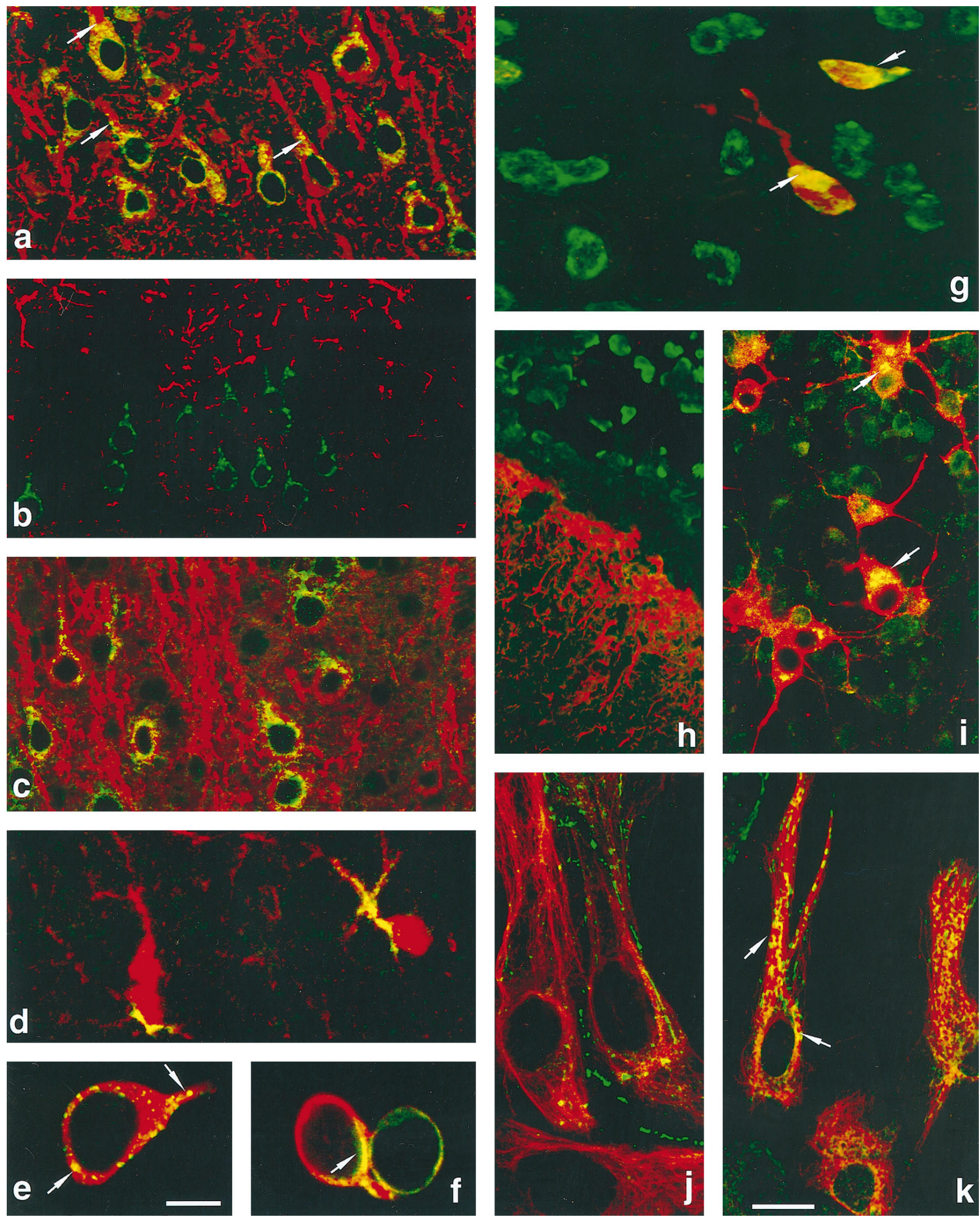

Figure 8. Double-immunolabeled confocal microscope images of tissue sections $(a-d)$, acute preparations of cortical cells $(e, f)$, and dissociated cell cultures $(i-k)$ labeled with $\mathrm{Cx} 26$ or 43 antibodies (stained green) and cell-specific markers (stained red). $g$, $h$, Sections processed for in situ hybridization for Cx 26 mRNA (stained green) immunolabeled with cell-specific markers (stained red); colocalization appears yellow. $a$, Cx 26 staining is colocalized with MAP-2 immunoreactivity in a number of neuronal somata and proximal dendrites. Some of these neurons were pyramidal cells with apical dendrites (arrows) oriented toward the pia. $b$, Absence of colocalization of $\mathrm{Cx} 26$ and GFAP in astrocytic processes. $c, \mathrm{Cx} 43$ labeling in neurons positive for MAP-2 (Figure legend continues) 
of these experiments indicate that (1) early in culture, Cx 43 is expressed by undifferentiated neuroepithelial cells and/or radial glia; (2) at later stages, Cx 43 is expressed in astrocytes and, possibly, in neurons; and (3) $\mathrm{Cx} 26$ is expressed in cortical neurons. These findings are consistent with and reinforce results of the cellular localization of Cxs in tissue sections.

\section{Biochemical analysis of Cxs during postnatal development \\ Western blotting}

Analysis of samples of visual cortex and liver by Western blotting showed the binding of the Cx 26 antibody to a band of $M_{\mathrm{r}} 22 \mathrm{k}$ corresponding to Cx 26 (Fig. 9a) Similarly, Cx 32 and 43 antibodies detected bands corresponding to $M_{\mathrm{r}} 27 \mathrm{k}$ (in visual cortex and liver) and $M_{\mathrm{r}} 43 \mathrm{k}$ proteins (in samples of heart) (Fig. 9b,c). The pattern of relative expression of Cxs in Western blots of visual cortex at P0, P7, P14, and P21 mirrored closely the developmental profile of these antigens observed in immunolabeled sections from brains of corresponding ages. Cx 26, present at low levels at P0, showed a dramatic increase in the next 2 weeks, an observation consistent with the immunocytochemical picture. Bands of $M_{\mathrm{r}} 27$ and $43 \mathrm{k}$, corresponding to Cxs 32 and 43, were detected at low levels at P7 and thereafter showed higher levels of expression with development.

\section{Northern blotting}

Analysis of total RNA extracted from visual cortices at P0, P14, P28, and P42 rats by Northern blotting showed bands corresponding to transcripts of Cxs $26(2.8 \mathrm{~kb}), 32(1.6 \mathrm{~kb})$, and $43(3.0 \mathrm{~kb})$ (Fig. $9 d-f$ ). Densitometric analysis (Fig. $9 h$ ) of these bands confirmed the general trend shown by the immunocytochemical and immunoblot analyses of the differential expression of the three Cxs during postnatal development. Thus, Cx 26 mRNA was abundant between birth and P14, whereas mRNA of Cxs 32 and 43 was present from as early as P0 and increased with age. RT-PCR studies, although confirming the presence of mRNA encoding Cxs 26, 32, and 43, also indicated the presence of $\mathrm{Cx} 37$, an endothelial Cx (Paul, 1995) (data not shown). This Cx was probably expressed in blood vessels present in all samples of the developing cortex analyzed.

\section{DISCUSSION}

We have studied the expression levels of Cxs, the constituent proteins of gap junctions, at the morphological, mRNA, and protein level during development of the rat cerebral cortex. The main conclusions to emerge from this study are the following. (1) Gap junctions are abundantly present from the early stages of corticogenesis through to maturation. (2) Each $\mathrm{Cx}$ examined shows a unique pattern of development. Cx 43 is present during the entire period of development, whereas Cx 26 expression is highest prenatally and during the first 3 weeks of postnatal life; $\mathrm{Cx}$ 32 is expressed exclusively postnatally. (3) Cx 26 is localized in neurons and may take part in the establishment of neuronal coupling in the developing cortex. (4) $\mathrm{Cx} 43$ is expressed in astrocytes as well as in a subpopulation of cortical neurons; it is also present in radial glial fibers, suggesting a possible role for this gap junction protein in neuronal migration.

\section{Gap junctions and expression of Cxs during corticogenesis}

Much is now known about the formation of the cerebral cortex: the generation, migration, and differentiation of the neurons and glia, the ingrowth of fibers and specification of the different cortical areas, and the occurrence of transient events during its development (Berry, 1974; McConnell, 1988; Uylings et al., 1990; Rakic, 1995). The generation of the diverse array of neurons and glia that form the cortex is the main event in the early stages of its development. In rats, cortical neurogenesis takes place between E14 and E21. The generation of the glial cell types also begins at about the same time but continues into postnatal life. At E12, when the telencephalic vesicles first appear, the primordial cortical neuroepithelium is seen as a pseudostratified germinal matrix comprising tightly packed dividing stem cells (Sauer, 1935). The presence of $\mathrm{Cx} 26$ in the cortical neuroepithelium during the period of intense cell proliferation suggests that this gap junction protein may be involved in the control of cell generation. It is notable that $\mathrm{Cx} 26$ labeling reaches its highest levels at the peak of neurogenesis (E14-E16) and diminishes considerably toward the end of gestation, a period during which proliferation declines. Evidence that gap junctions are permeant to mitogens and morphogens (Caveney, 1985; Guthrie and Gilula, 1989) also supports the notion that they may play a role in cell proliferation (Lowenstein, 1981). The presence of Cxs 26 and 43 in the proliferative zones of the developing cortex suggests that these Cxs may also be involved in other developmental events, such as laminar specification (McConnell and Kaznowski, 1991) and cell phenotype determination (Luskin et al., 1993; Mione et al., 1994).

A major function frequently attributed to gap junctional communication in the nervous system is pattern formation (Warner et al., 1984; Caveney, 1985; Fulton, 1995). Also, gap junctions may be linked with the migration of neural crest and sclerotomal cells (Ruangvoravat and Lo, 1992). In neocortical development, according to the radial unit hypothesis of Rakic (1988), the ventricular zone consists of proliferative units that provide a protomap of prospective cytoarchitectonic areas. In such a model, the relative spatial positions between cohorts of cells in the ventricular zone may be specified by the exchange of diffusible signals through gap junctions, thereby enabling migrating cells to maintain their spatial positions and contribute to the formation of areas in the cortex. These cohorts of cells migrate with the aid of radial glia to their destinations in the cortical plate (Rakic, 1972), and there is evidence (LoTurco and Kriegstein, 1991) that cells within individual radial units are coupled by gap junctions. Radial glia, the first

\section{$\leftarrow$}

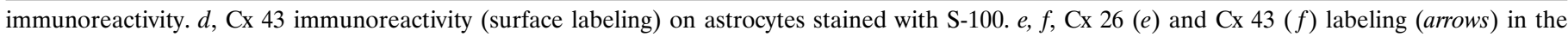

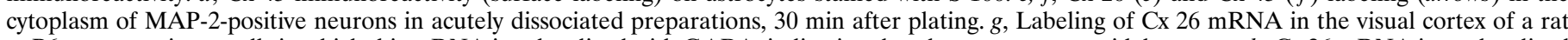

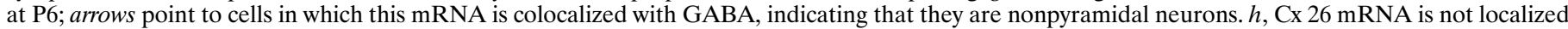

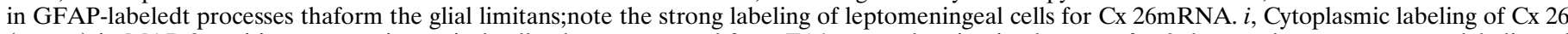

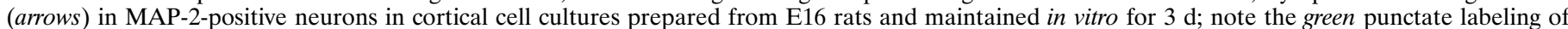

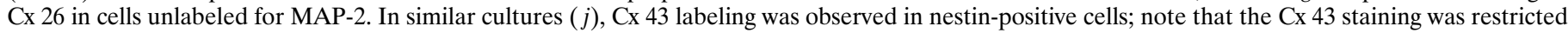

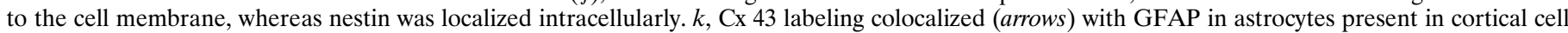

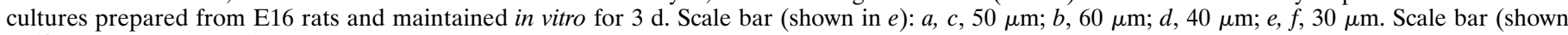
in $k): g, i, 30 \mu \mathrm{m} ; h, j, k, 40 \mu \mathrm{m}$. 


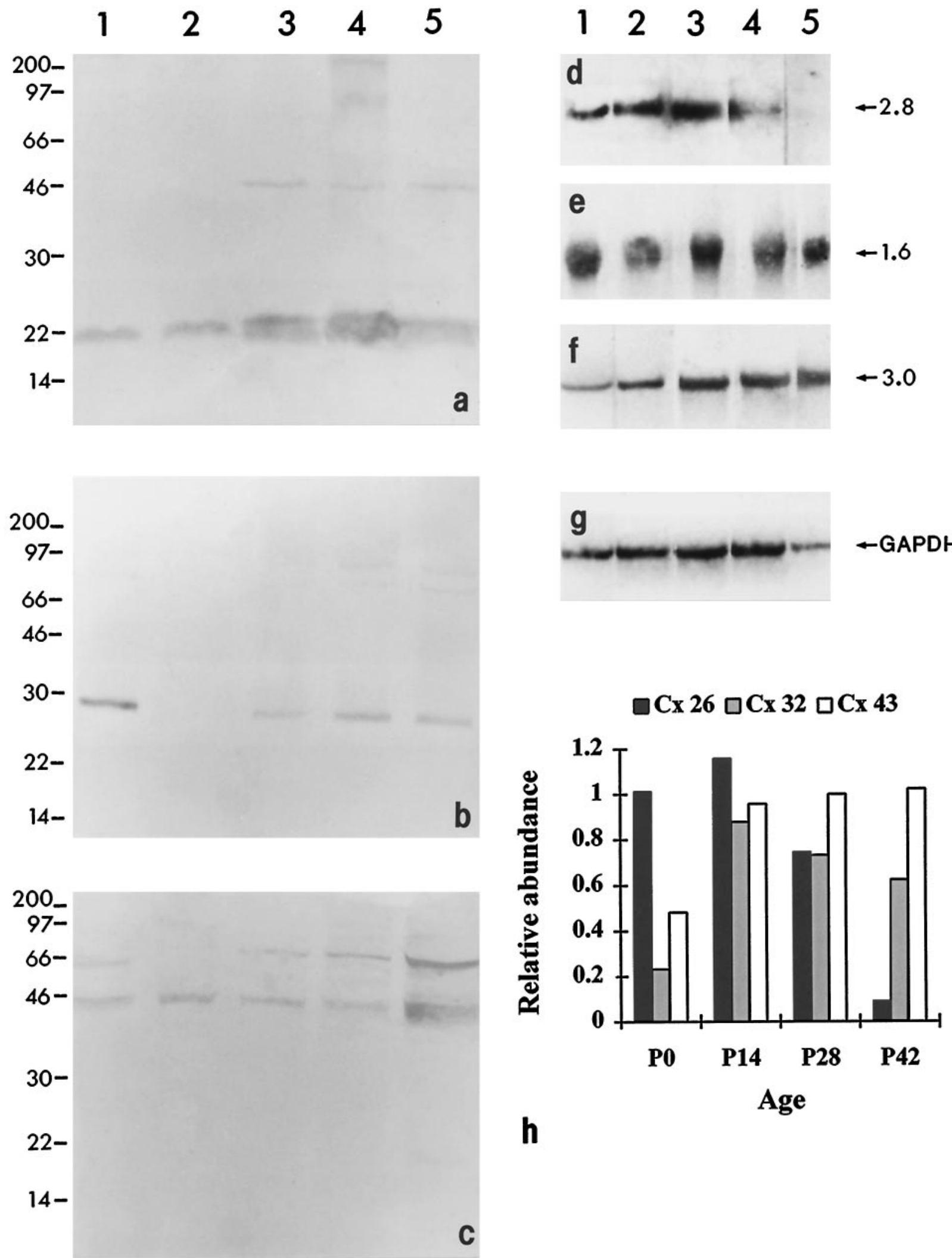

Figure 9. Localization of Cxs in Western and Northern blots of control (liver or heart) and cortical tissues. Western blots of samples labeled for Cxs 26 $(a), 32(b)$, and 43 (c); lane 1 corresponds to samples of control tissues (liver, Cxs 26 and 32; heart, Cx 43), and lanes 2-5 correspond to samples of visual cortex of rats at P0, P7, P14, and P21. a, Cx 26 antibody detected bands corresponding to $M_{\mathrm{r}} 22$ k protein in liver and visual cortex of P0, P7, P14, and P21 rats, with occasional faint labeling of bands at higher molecular weights. Note the increase in the intensity of signal between P0 and P14 (lanes 2-4). $b$, Cx 32 antibody detected bands corresponding to $M_{\mathrm{r}} 27 \mathrm{k}$ in liver and visual cortex of P7, P14, and P21 animals. Note the absence of signal at P0 (lane 2). c, Cx 43 antibody detected a prominent band at $M_{\mathrm{r}} 43 \mathrm{k}$ in heart and brain samples, in addition to a band at $M_{\mathrm{r}} 66 \mathrm{k}$, as (Figure legend continues) 
glial cells to appear during development (Levitt and Rakic, 1980), have their cell bodies located in the proliferative zones, with processes extending toward the ventricular surface and the pia. The presence of Cx 43 in radial glial fibers during the period of neuronal migration suggests that neurons establish contact and communication with the scaffolding they use as they migrate to the cortical plate. As neuronal migration tapers off, radial glial cells are transformed into fibrillary and protoplasmic astrocytes (Choi and Lapham, 1978; Schmechel and Rakic, 1979) and are added to the existing population of astrocytes known to form networks connected by gap junctions in the cortex (Bennett and Goodenough, 1978; Massa and Mugnaini, 1982; Yamamoto et al., 1990). The localization of $\mathrm{Cx} 43$ in radial glia indicates that these cells possess the necessary Cxs to form gap junctions. This notion is supported by our finding that gap junctions are located between cellular elements that show features of the astroglial phenotype at the time neuronal migration is known to take place. It is supported further by the demonstration of gap junctions between nestin-positive (presumptive radial glia) and nestin-negative cells in the ventricular surface at similar developmental stages.

\section{Postnatal expression of Cxs}

The different patterns of expression of Cxs 26, 32, and 43 occurring postnatally suggest that the cortex may require a complement of these proteins during the different stages of its development. At birth, Cxs 26 and 43 are present in the infragranular layers. With time, both Cxs appear progressively in the more superficial layers and follow an "inside-out" pattern similar to that described for the generation and differentiation of the cortical cell types (Parnavelas and Lieberman, 1979; Miller, 1981, 1988; Dori and Parnavelas, 1996); however, although the localization and pattern of expression of Cx 43 mirrors the maturation of the cortex throughout postnatal development, the expression of $\mathrm{Cx} 26$ is a transient event remaining high until the end of the second postnatal week and diminishing thereafter. The mRNA transcripts for this antigen also reach peak levels at the end of the second week and subsequently decline until they are hardly detected at the end of the fourth week, suggesting a downregulation in the production of Cx 26 in the third week of life. Cx 32 was not detected immunocytochemically until the end of the first week, in agreement with the Western blot analysis; higher levels of expression appeared later in development. Cx 32 mRNA, however, was detected in the cortex of newborn animals when no protein was found. This observation can be accounted for by the fact that mRNA and protein levels are not always directly related and by differences in the level of sensitivity of the techniques used. Also, turnover periods of mRNA and its Cx product may vary, and the Cxs, although not glycosylated, are highly likely to be subject to post-translational modification.

We speculate that the changes observed in the expression of Cxs postnatally are of physiological significance, because it coincides with important events in cortical development. The 2 week period after birth is critical in the development of the rat cerebral cortex, when the rates of morphological, neurochem- ical, and functional differentiation are highest (Blue and Parnavelas, 1983; Armstrong-James and Fox, 1988; Miller, 1988; Parnavelas et al., 1988; Uylings et al., 1990). At the same time, local neuronal circuits are identified in the cortex, and there has been speculation about the involvement of neuronal coupling through gap junctions in this developmental process (Peinado et al., 1993a,b). The presence of extensive dye coupling between neighboring cells can allow local groups of neurons to exchange developmentally important signals. The disappearance of dye coupling after the third postnatal week (Connors et al., 1983; Peinado et al., 1993b), and the observation that expression of $\mathrm{Cx} 26$ matched closely the pattern of development of neuronal coupling, suggests that this protein takes part in the establishment of functional coupling during the formation of neuronal circuits in the cortex. Our immunocytochemical and in situ hybridization experiments demonstrated intense labeling in somata and dendrites of neurons, consistent with the observation that most coupling sites between cortical neurons occur at dendrosomatic and dendrodendritic contacts (Peinado et al., 1993a).

The increase in $\mathrm{Cx} 43$ expression, generally associated with astrocytes (Dermietzel and Spray, 1993), during postnatal development correlates with the generation of astrocytes in the neocortex (Parnavelas et al., 1983). The localization of $\mathrm{Cx} 43$ in populations of neurons may facilitate neuron-astrocytic interactions (Charles, 1994; Nedergaard, 1994; Nedergaard et al., 1995), in agreement with the identification of $\mathrm{Cx} 43$ in neurons of adult cortex and the demonstration of gap junctions between neurons and astrocytes (Nadarajah et al., 1996). These results indicate that Cx 43 is not expressed transiently in certain neuronal cell types, but its expression persists in these cells during development and in the adult cortex. Cx 32 has been demonstrated exclusively in neurons in the developing and adult cerebral cortex (Dermietzel et al., 1989; Micevych and Abelson, 1991; Nadarajah et al., 1996). We now show, however, that this $\mathrm{Cx}$ is unlikely to mediate the physiological neuronal coupling reported in the cortex, because it is expressed at higher levels at the later stages of the developmental period, when neuronal coupling diminishes. Alternatively, gap junctions constructed mainly of $\mathrm{Cx} 32$ may serve to mediate rhythmic subthreshold oscillations responsible for synchronized neuronal firing during the late stages of cortical development (Llinas et al., 1991; Peinado et al., 1993b). Taken together, the findings presented here indicate multiple roles for Cxs in neocortical formation.

\section{REFERENCES}

Armstrong-James M, Fox K (1988) The physiology of developing cortical neurons. In: Cerebral cortex, Vol 7: Development and maturation of cerebral cortex (Peters A, Jones EG, eds), pp 237-272. New York: Plenum.

Bayer SA, Altman J (1991) Neocortical development. New York: Raven. Becker DL, Evans WH, Green CR, Warner A (1995) Functional analysis of amino acid sequences in connexin 43 involved in intercellular communication through gap junctions. J Cell Sci 108:1455-1467.

reported by Beyer et al. (1989). The position of the molecular mass markers is given on the left. $d-g$, Northern blots of samples labeled for Cxs 26,32 , and 43, and GAPDH transcripts; lane 1 corresponds to control tissues (liver or heart), and lanes 2-5 correspond to samples of visual cortex of rats at P0, $\mathrm{P} 14, \mathrm{P} 28$, and P42. $d$, Cx 26 antisense RNA probes detected a band corresponding to $2.8 \mathrm{~kb}$ in liver and brain samples. Note the abundance of Cx 26 mRNA between $\mathrm{P} 0$ and $\mathrm{P} 14 . e, \mathrm{Cx} 32$ riboprobes detected a band corresponding to $1.6 \mathrm{~kb}$ in liver and brain samples. $f$, Cx 43 antisense probes detected a $3 \mathrm{~kb}$ band in heart and brain samples. $g$, GAPDH standard. $h$, Histogram illustrating the differential expression and relative abundance of Cxs mRNA in the visual cortex at four stages of postnatal development. 
Bennett MV, Goodenough DA (1978) Gap junctions, electrotonic coupling, and intercellular communication. Neurosci Res Program Bull 16:373-485.

Bennett MVL, Barrio LC, Bargiello TA, Spray DC, Hertzberg E, Saez JC (1991) Gap junctions: new tools, new answers, new questions. Neuron 6:305-320.

Berry M (1974) Development of the cerebral neocortex of the rat. In: Studies on the development of behavior and the nervous system, Vol 2: Aspects of neurogenesis (Gottlieb G, ed), pp 7-67. New York: Academic.

Beyer EC, Paul DL, Goodenough DA (1987) Connexin 43: a protein from rat heart homologous to gap junction protein from liver. J Cell Biol 105:2621-2629.

Beyer EC, Kistler J, Paul DL, Goodenough DA (1989) Antisera directed against connexin 43 peptides react with a $43-\mathrm{kd}$ protein localised to gap junctions in myocardium and other tissues. J Cell Biol 108:595-605.

Blue ME, Parnavelas JG (1983) The formation and maturation of synapses in the visual cortex of the rat. I. Qualitative analysis. J Neurocytol 12:599-616.

Brightman MW, Reese TS (1969) Junctions between intimately apposed cell membranes in the vertebrate brain. J Cell Biol 40:648-677.

Cameron RS, Rakic P (1991) Glial cell lineage in the cerebral cortex: a review and synthesis. Glia 4:124-137.

Carter TD, Chen XY, Carlile G, Kalapothakis E, Ogden D, Evans WH (1996) Porcine aortic endothelial gap junctions: identification and permeation by caged InsP3. J Cell Sci 109:1765-1773.

Caveney S (1985) The role of gap junctions in the development. Annu Rev Physiol 47:319-335.

Charles AC (1994) Glia-neuron intercellular calcium signalling. Dev Neurosci 16:196-206.

Choi BH, Lapham LW (1978) Radial glia in the human fetal cerebrum: a combined Golgi, immunofluorescent and electron microscopic study. Brain Res 148:295-311.

Connors BW, Benardo LS, Prince DA (1983) Coupling between neurons of the developing rat neocortex. J Neurosci 3:773-782.

Dermietzel R, Spray DC (1993) Gap junctions in the brain: where, what type, how many and why? Trends Neurosci 16:186-192.

Dermietzel R, Traub O, Hwang TK, Beyer E, Bennett MVL, Spray DC, Willecke K (1989) Differential expression of three gap junction proteins in the developing and mature brain tissues. Proc Natl Acad Sci USA 86:10148-10152.

Dori I, Parnavelas JG (1996) The development of excitatory transmitter amino acid-containing neurons in the rat visual cortex: a light and electron microscopic immunocytochemical study. Exp Brain Res 110:347-359.

Fulton BP (1995) Gap junctions in the developing nervous system. Perspect Dev Neurobiol 2:327-334.

Gourdie RG, Green CR, Severs NJ (1991) Gap junction distribution in adult mammalian myocardium revealed by an anti-peptide antibody and laser scanning confocal microscopy. J Cell Sci 99:41-55.

Guthrie SC, Gilula NB (1989) Gap junctional communication and development. Trends Neurosci 12:12-15.

Hertzberg EL (1984) A detergent-independent procedure for the isolation of gap junctions from rat liver. J Biol Chem 259:9936-9943.

Krieg WJS (1946) Connections of the cerebral cortex. I. The albino rat A: topography of the cortical areas. J Comp Neurol 84:221-276.

Kumar NM, Gilula NB (1996) The gap junction communication channel. Cell 84:381-388.

Laemmli UK (1970) Cleavage of structural proteins during the assembly of the head of bacteriophage T4. Nature 227:680-685.

Levitt P, Rakic P (1980) Immunoperoxidase localization of glial fibrillary acidic protein in radial glial cells and astrocytes of the developing rhesus monkey brain. J Comp Neurol 193:815-840.

Llinas RR, Grace AA, Yarom Y (1991) In vitro neurons in mammalian cortical layer 4 exhibit intrinsic oscillatory activity in the $10-$ to $50-\mathrm{Hz}$ frequency range. Proc Natl Acad Sci USA 88:897-901.

LoTurco JJ, Kriegstein AR (1991) Clusters of coupled neuroblasts in embryonic neocortex. Science 252:563-566.

Lowenstein WR (1981) Junctional intercellular communication: the cellto-cell membrane channel. Physiol Rev 61:829-913.

Luskin MB, Parnavelas JG, Barfield JA (1993) Neurons, astrocytes, and oligodendrocytes of the rat cerebral cortex originate from separate progenitor cells: an ultrastructural analysis of clonally related cells. J Neurosci 13:1730-1750.

Massa PT, Mugnaini E (1982) Cell junctions and intramembrane particles of astrocytes and oligodendrocytes: a freeze-fracture study. Neuroscience 7:523-538.

McConnell SK (1988) Development and decision-making in the mammalian cerebral cortex. Brain Res Rev 13:1-23.

McConnell SK, Kaznowski CE (1991) Cell cycle dependence of laminar determination in developing neocortex. Science 254:282-285.

Micevych PE, Abelson L (1991) Distribution of mRNAs coding for liver and heart gap junctions proteins in the rat central nervous system. J Comp Neurol 305:96-118.

Miller M (1981) Maturation of rat visual cortex. I. A quantitative study of Golgi-impregnated pyramidal neurons. J Neurocytol 10:859-878.

Miller MW (1988) Maturation of rat visual cortex. IV. The generation, migration, morphogenesis, and connectivity of atypically oriented pyramidal neurons. J Comp Neurol 274:387-405.

Mione MC, Boardman P, Harris B, Parnavelas JG (1994) Lineage analysis reveals neurotransmitter (GABA or glutamate) but not calciumbinding protein homogeneity in clonally related cortical neurons. J Neurosci 14:107-123.

Monaghan P, Perusinghe N, Carlile G, Evans WH (1994) Rapid modulation of gap junction expression in mouse mammary gland during pregnancy, lactation and involution. $\mathrm{J}$ Histochem Cytochem 42:931-938.

Monaghan P, Clarke C, Perusinghe NP, Moss DW, Chen XY, Evans WH (1996) Gap junction distribution and connexin expression in human breast. Exp Cell Res 223:29-38.

Nadarajah B, Thomaidou D, Evans WH, Parnavelas JG (1996) Gap junctions in the adult cerebral cortex: regional differences in their distribution and cellular expression of connexins. J Comp Neurol 376:326-342.

Nedergaard M (1994) Direct signalling from astrocytes to neurons in culture of mammalian brain cells. Science 263:1768-1771.

Nedergaard M, Cooper AJL, Goldman SA (1995) Gap junctions are required for the propagation of spreading depression. J Neurobiol 28:433-444.

Nicholson B, Dermietzel R, Teplow D, Traub O, Willecke K, Revel JP (1987) Two homologous protein components of hepatic gap junctions. Nature 329:732-734.

Parnavelas JG, Lieberman AR (1979) An ultrastructural study of the maturation of neuronal somata in the visual cortex of the rat. Anat Embryol 157:311-328.

Parnavelas JG, Luder R, Pollard SG, Sullivan K, Lieberman AR (1983) A qualitative and quantitative ultrastructural study of glial cells in the developing visual cortex of the rat. Phil Trans R Soc Lond [Biol] 301:55-84.

Parnavelas JG, Papadopoulos GC, Cavanagh ME (1988) Changes in neurotransmitters during development. In: Cerebral cortex (Peters A, Jones EG, eds), pp 177-209. New York: Plenum.

Paul DL (1986) Molecular cloning of cDNA for rat liver gap junction protein. J Cell Biol 103:123-134.

Paul DL (1995) New functions for gap junctions. Curr Opin Neurobiol 7:665-672.

Peinado A, Yuste R, Katz LC (1993a) Extensive dye coupling between rat neocortical neurons during the period of circuit formation. Neuron 10:103-114.

Peinado A, Yuste R, Katz LC (1993b) Gap junctional communication and the development of local circuits in neocortex. Cerebral Cortex 3:488-498.

Rahman S, Evans WH (1991) Topography of connexin32 in rat liver gap junctions. Evidence for an intramolecular disulphide linkage connecting the two extracellular peptide loops. J Cell Sci 100:567-578.

Rahman S, Carlile G, Evans WH (1993) Assembly of hepatic gap junctions. Topography and distribution of connexin 32 in intracellular and plasma membranes determined using sequence-specific antibodies. J Biol Chem 268:1260-1265.

Rakic P (1972) Mode of cell migration to the superficial layers of fetal monkey neocortex. J Comp Neurol 145:61-84.

Rakic P (1988) Specification of cerebral cortical areas. Science 241:170-176.

Rakic P (1995) A small step for the cell, a giant leap for mankind: a 
hypothesis of neocortical expansion during evolution. Trends Neurosci 18:383-388.

Ruangvoravat CP, Lo CW (1992) Connexin 43 expression in the mouse embryo: localization of transcripts within developmentally significant domains. Dev Dynamics 194:261-281.

Sauer FC (1935) Mitosis in the neural tube. J Comp Neurol 62:377-405.

Schmechel DE, Rakic P (1979) A Golgi study of radial glial cells in developing monkey telencephalon: morphogenesis and transformation into astrocytes. Anat Embryol Berl 156:115-152.

Uylings HBM, Van Eden CG, Parnavelas JG, Kalsbeek A (1990) The prenatal and postnatal development of rat cerebral cortex. In: The cerebral cortex of the rat (Kolb B, Tees RC, eds), pp 35-76. Cambridge, MA: MIT Press.

Warner AE, Guthrie SC, Gilula NB (1984) Antibodies to gap-junctional protein selectively disrupt junctional communication in the early amphibian embryo. Nature 311:127-131.

Yamamoto T, Ochalski A, Hertzberg EL, Nagy JI (1990) On the organization of astrocytic gap junctions in the rat brain as suggested by LM and EM immunohistochemistry of connexin 43 expression. J Comp Neurol 302:853-883.

Yuste R, Peinado A, Katz LC (1992) Neuronal domains in developing neocortex. Science 257:665-668.

Yuste R, Nelson DA, Rubin WW, Katz LC (1995) Neuronal domains in developing neocortex: mechanisms of coactivation. Neuron 14:7-17.

Zhang JT, Nicholson BJ (1989) Sequence and tissue distribution of a second protein of hepatic gap junctions, Cx26, as deduced from its cDNA. J Cell Biol 109:3391-3401. 